\title{
Quantifying the impact of ocean acidification on our future climate
}

\author{
R. J. Matear and A. Lenton \\ Centre for Australian Weather and Climate Research (CAWCR). A partnership between CSIRO and the Bureau of \\ Meteorology; CSIRO Marine and Atmospheric Research, CSIRO Marine Laboratories, GPO Box 1538, Hobart, Tasmania, \\ Australia
}

Correspondence to: R. J. Matear (richard.matear@csiro.au)

Received: 21 September 2013 - Published in Biogeosciences Discuss.: 12 November 2013

Revised: 23 May 2014 - Accepted: 6 June 2014 - Published: 30 July 2014

\begin{abstract}
Ocean acidification (OA) is the consequence of rising atmospheric $\mathrm{CO}_{2}$ levels, and it is occurring in conjunction with global warming. Observational studies show that OA will impact ocean biogeochemical cycles. Here, we use an Earth system model under the RCP8.5 emission scenario to evaluate and quantify the first-order impacts of OA on marine biogeochemical cycles, and its potential feedback on our future climate. We find that $\mathrm{OA}$ impacts have only a small impact on the future atmospheric $\mathrm{CO}_{2}$ (less than $45 \mathrm{ppm}$ ) and global warming (less than a $0.25 \mathrm{~K}$ ) by 2100 . While the climate change feedbacks are small, OA impacts may significantly alter the distribution of biological production and remineralisation, which would alter the dissolved oxygen distribution in the ocean interior. Our results demonstrate that the consequences of $\mathrm{OA}$ will not be through its impact on climate change, but on how it impacts the flow of energy in marine ecosystems, which may significantly impact their productivity, composition and diversity.
\end{abstract}

\section{Introduction}

The oceans have taken up approximately a third of the total fossil fuel $\mathrm{CO}_{2}$ emitted to the atmosphere since the onset of industrialisation ( $140 \pm 25 \mathrm{PgC}$, (Khatiwala et al., 2009)). This uptake has slowed the rate of global warming, but has led to detectable changes in the ocean chemistry (e.g. Doney et al., 2009). As the $\mathrm{CO}_{2}$ enters the ocean, primarily through sea-air fluxes, it reacts with the seawater and reduces the carbonate ion concentration and $\mathrm{pH}$, collectively known as ocean acidification (OA). This uptake of anthropogenic $\mathrm{CO}_{2}$ has reduced the $\mathrm{pH}$ of the modern ocean surface waters by 0.1 units or hydrogen ion concentration $\left(\left[\mathrm{H}^{+}\right]\right)$by $30 \%$ since preindustrial times (Caldeira, 2005). By the end of this century, under the higher emission scenarios, the projected $\left[\mathrm{H}^{+}\right]$ change since preindustrial times maybe greater than $100 \%$ (Orr et al., 2005).

OA has the potential to affect the major biogeochemical (BGC) cycles in the ocean (Gehlen et al., 2011), with potentially significant consequences for our future climate (Matear et al., 2010). In assessing the potential OA impacts on BGC cycles and climate, it is important to recognise that ocean acidification impacts do not occur in isolation, but they are associated with global warming, which may modulate their impacts (e.g. Brewer and Peltzer, 2009). Therefore, assessing the future impacts of OA requires an Earth System Model (ESM) that considers the interactive effects of global warming and OA on BGC cycling (Tagliabue et al., 2011). The goal of this study is to use an ESM to evaluate and quantify the first-order impacts and climate feedbacks of OA. To do this, we first review the potential for ocean acidification to alter the major BGC cycles. We then use our ESM to assess how these modulations of the BGC by OA alter the projected climate in the current century. From our simulations, we then discuss how the OA-modulated BGC changes affect the ocean environment. Finally, we conclude with a discussion of $\mathrm{OA}$ impacts on $\mathrm{BGC}$ cycling and climate that require further investigation.

\section{Potential impacts of ocean acidification on BGC cycles}

Ocean acidification has the potential to modify marine BGC cycles in a number of ways, which could alter the future climate. We define the term BGC climate feedback to denote an oceanic BGC process that may either enhance (positive 
feedback) or reduce (negative feedback) global warming due to rising or respectively decreasing greenhouse gases. For this study, we primarily focus on marine BGC processes that are impacted by $\mathrm{OA}$ and global warming, which can alter oceanic uptake of carbon.

To aid the discussion of the potential impacts of OA on BGC cycles, we separate the impacts into processes that (1) alter biological production in the photic zone; and (2) alter the remineralisation of sinking particulate organic and inorganic carbon in the ocean interior. These processes are summarised in Table 1, with an indication of the sign the impact has on global warming based on published studies.

\subsection{Biological production}

The rising $\mathrm{CO}_{2}$ levels in the upper ocean has the potential to affect biological production in several ways:

1. Increase net primary productivity by making photosynthesis more efficient (Rost et al., 2008). Experimental studies have also shown an increase in particulate organic carbon (POC) production in response to increased levels of $\mathrm{CO}_{2}$ (e.g. Zondervan et al., 2002).

2. Alter the stoichiometric nutrient to carbon ratio of the exported particulate organic matter, which enables ocean biology to partially overcome nutrient control on carbon production and export. Mesocosm experiments with natural plankton communities have reported an increased $\mathrm{C} / \mathrm{N}$ ratio of particulate organic matter under elevated $\mathrm{CO}_{2}$ (Riebesell et al., 2007; Bellerby et al., 2008). In these experiments, the $\mathrm{C} / \mathrm{N}$ ratio increased from 6.0 at $350 \mu$ atm to 8.0 at about $1050 \mu \mathrm{atm}$. An increase in the $\mathrm{C} / \mathrm{N}$ ratio of the export POC with a fixed $\mathrm{C} / \mathrm{O}$ ratio would result in increased carbon storage and increased oxygen consumption in the ocean (Oschlies et al., 2008).

3. Impact the ability of organisms to calcify (Fabry et al., 2008). This is anticipated to reduce the production of calcium carbonate. Due to the nature of the carbonate chemistry, reduced calcium carbonate production allows the upper ocean to increase its carbon uptake (Raven, 2005; Heinze, 2004; Hutchins, 2011).

All three of these affects would increase the storage of carbon in the ocean and provide a negative feedback to climate warming.

\subsection{Remineralisation of particulate material}

Most of the exported POC is remineralised in the upper $1000 \mathrm{~m}$, but $\approx 10 \%$ escapes to the deep ocean, where it is remineralised or buried in sediments, and sequestered from the atmosphere on millennium timescales (Trull et al., 2001). Analysis of particulate inorganic carbon (PIC) and POC fluxes at water depths greater than $1000 \mathrm{~m}$ suggests a close association between these fluxes (Armstrong et al., 2002). The ratio of PIC production to POC is called the rain ratio (e.g. Archer et al., 2000). OA has the potential to impact the remineralisation of sinking particulate material in the following ways:

1. Dissolution of $\mathrm{CaCO}_{3}$ is an abiotic process driven by thermodynamics, and the rate of dissolution is related to the saturation state of the ocean (Orr et al., 2005). Chemical dissolution can occur when the saturation state of $\mathrm{CaCO}_{3}$ falls below 1 (or below the lysocline). As the lysocline moves toward the surface with ocean acidification, increased dissolution of $\mathrm{CaCO}_{3}$ sediments and sinking particles will increase the alkalinity in the ocean (Ridgwell et al., 2009). This potentially increases the supply of alkalinity to the upper ocean (increasing $\mathrm{CO}_{2}$ uptake), which acts as a negative climate feedback.

2. (Armstrong et al., 2002) proposed that $\mathrm{CaCO}_{3}$ acts as a carrier for transporting POC to the deep ocean by ballasting the POC, thereby increasing its sinking speed. It is also hypothesised that the association between $\mathrm{CaCO}_{3}$ and POC might protect the latter from bacterial degradation (Armstrong et al., 2002). If deep-water POC fluxes are controlled by $\mathrm{CaCO}_{3}$, then a decrease in the $\mathrm{CaCO}_{3}$ production would result in a decreased $\mathrm{POC}$ transport to the deep ocean. Consequently, POC would remineralise at shallower depths and therefore the net efficiency of the biological pump would decrease, resulting in a positive climate feedback.

3. The remineralisation length scale of POC is dependent on microbial activity. It has been hypothesised that ocean acidification may increase the rate of microbial activity (Weinbauer et al., 2011), leading to more rapid remineralisation of sinking POC, which would result in less carbon sequestration, and a positive climate feedback. A warming ocean may further accelerate microbial activity (Rivkin, 2001) and cause more rapid remineralisation of sinking POC.

In summary, changing the strength of the biological pump can have either a positive or negative feedback on climate warming.

\section{Earth system model and simulations}

\subsection{Earth system model}

For the simulations presented here an Earth system model was used (Mk3L-COAL). Mk3L-COAL includes a climate model, Mk3L (Phipps et al., 2011), coupled to a biogeochemical model of carbon, nitrogen and phosphorus cycles on land (CASA-CNP) in the Australian community land surface model, CABLE (Wang et al., 2010; Mao et al., 2011), and an ocean biogeochemical cycle model (Matear and Hirst, 
Table 1. Potential ocean acidification impacts on BGC cycles. A positive value in the Impact on global warming column signifies the process causes greater warming (positive feedback).

\begin{tabular}{lc}
\hline Biological production & \\
\hline Process & Impact on global warming \\
Increased net primary productivity & - \\
Increased export of organic matter & - \\
Increased C / P and C / N ratio of organic matter & - \\
Reduced calcification & - \\
\hline Remineralisation of sinking organic matter & \\
\hline Process & Impact on global warming \\
Increasing microbial POC remineralisation & + \\
Reduced ballasting with calcium carbonate & + \\
\hline
\end{tabular}

2003; Duteil et al., 2012). The details of the ocean biogeochemical model are summarised in the Appendix.

The atmosphere model has a horizontal resolution of $5.6^{\circ} \mathrm{C}$ by $3.2^{\circ} \mathrm{C}$, and 18 vertical layers. The land carbon model has the same horizontal resolution as the atmosphere. The ocean model has a resolution of $2.8^{\circ} \mathrm{C}$ by $1.6^{\circ} \mathrm{C}$, and 21 vertical levels. Mk3L simulates the historical climate well, as compared to the models used for earlier IPCC assessments (Phipps et al., 2011; Pitman et al., 2011). Furthermore, the simulated response of the land carbon cycle to increasing atmospheric $\mathrm{CO}_{2}$ and warming are consistent with those from the Coupled Model Intercomparison Project Phase 5 (CMIP5) (Zhang et al., 2014). The ocean biogeochemical model was shown to realistically simulate the global ocean carbon cycle (Duteil et al., 2012). Previous studies with this ocean biogeochemical model have shown to realistically simulate anthropogenic carbon and CFC uptake by the ocean (Matsumoto et al., 2004). We referred to the ocean BGC formulation used in these previous studies as our standard BGC formulation, which is then modified to incorporate OA impacts.

The land model (CABLE) with CASA-CNP simulates the temporal evolution of heat, water and momentum fluxes at the surface, as well as the biogeochemical cycles of carbon, nitrogen and phosphorus in plants and soils. For this study, we used the spatially explicit estimates of nitrogen deposition for 1990 (Dentener, 2006). The simulated (Zhang et al., 2014) geographic variations of nutrient limitations, major biogeochemical fluxes and pools on the land under the present climate conditions are consistent with published studies (Wang et al., 2010; Hedin, 2004).

\subsection{Model simulations}

The ESM was spun up under preindustrial atmospheric $\mathrm{CO}_{2}$ (1850: $284.7 \mathrm{ppm}$ ) until the simulated climate became stable. Stability was defined as the linear trend of global mean surface temperature over the last 400 years of the spin-up being less than $0.015 \mathrm{~K}$ per century.
For the historical period (1850-2005), the ESM was run using the historical atmospheric $\mathrm{CO}_{2}$ concentrations as prescribed by the CMIP5 simulation protocol. For the historical period a reference simulation (REF) was performed where atmospheric $\mathrm{CO}_{2}$ affects both the radiative properties of the atmosphere and the carbon cycle (Table 2) (Zhang et al., 2014).

For the future, we used the RCP8.5 emissions scenario as provided by the CMIP5 (http://cmip-pcmdi.llnl.gov/cmip5/), and let our ESM, which has full carbon-climate interactions, determine the future atmospheric $\mathrm{CO}_{2}$ concentrations (Zhang et al., 2014). The RCP8.5 scenario is the highest $\mathrm{CO}_{2}$ emissions scenario used in the IPCC's Fifth Assessment Report, and in this scenario radiative forcing increases to $8.5 \mathrm{~W} \mathrm{~m}^{-2}$ by 2100 . For comparison, we also completed a standard CMIP5 simulation where RCP8.5 atmospheric $\mathrm{CO}_{2}$ concentrations were used rather than letting our ESM determine the future $\mathrm{CO}_{2}$ concentrations from the emission scenario (we called this simulation RCP8.5). As discussed by (Zhang et al., 2014), using RCP8.5 emissions rather than concentrations resulted in a slightly warmer world $(0.25 \mathrm{~K})$ by 2100 because of reduced land carbon uptake due to nutrient limitation. In all our simulations the vegetation scenario used by (Lawrence et al., 2013) remained unchanged over the simulation period following the CMIP5 experimental design. Note that the $\mathrm{CO}_{2}$ emissions from land use change were not included in our simulation, but are implicitly taken into account in the the RCP8.5 emission scenario. We also neglected changes in anthropogenic $\mathrm{N}$ deposition over the simulation period, because of the large uncertainty in the future deposition rate and the small impact it has on net land carbon uptake (Zaehle et al., 2010).

\subsection{Ocean acidification impacts on BGC}

To assess the potential impacts of OA on BGC cycles, we modified the ocean BGC formulation in the future period (2006-2100). These idealised modifications to the marine BGC cycle are summarised in Table 2 and described in more detail below. The modifications are designed to provide a 
Table 2. Summary of the ocean BGC experiments presented in this study. In all simulations, both the climate and the carbon components experience the impact of rising atmospheric $\mathrm{CO}_{2}$. The RCP8.5 simulation uses the prescribed atmospheric $\mathrm{CO}_{2}$ as provided by the CMIP5 for this scenario, while the others scenarios use the RCP8.5 emissions and the ESM determines the $\mathrm{CO}_{2}$ concentration. In the REF and RCP8.5 simulations, the formulation of the ocean BGC is not impacted by OA, while in the other simulations selected processes are modified to address the potential OA impacts. The REF simulation starts in 1850 using historical atmospheric $\mathrm{CO}_{2}$ (identical to RCP8.5) and switches to the RCP8.5 future emissions scenario at the start of 2006. The four other simulations (EP+, EP++, REMIN+ and COMB) start from the REF simulation at the end of 2005 and go until 2100 using the RCP8.5 future emissions. Please refer to the text for a description of how the BGC cycle is modified in the EP+, EP++, REMIN+ and COMB simulations.

\begin{tabular}{llc}
\hline Name & Description & Duration \\
\hline RCP8.5 & $\begin{array}{l}\text { Standard } \mathrm{BGC} \text { with historical atmospheric } \mathrm{CO}_{2} \text { and } \mathrm{RCP} 8.5 \text { future } \\
\text { atmospheric } \mathrm{CO}_{2}\end{array}$ & $1850-2100$ \\
$\mathrm{REF}$ & Standard $\mathrm{BGC}$ with historical atmospheric $\mathrm{CO}_{2}$ and $\mathrm{RCP} 8.5$ future emissions & $1850-2100$ \\
$\mathrm{EP}+$ & Increased $\mathrm{C} / \mathrm{P}$ ratio of POC export and reduced $\mathrm{PIC}$ as $\mathrm{CO}_{2}$ increased & $2006-2100$ \\
$\mathrm{EP}++$ & EP+ and increased POC export as $\mathrm{CO}_{2}$ increased & $2006-2100$ \\
REMIN+ & Increased rate of POC and PIC remineralisation as $\mathrm{CO}_{2}$ increased & $2006-2100$ \\
COMB & Combined affect of EP++ and REMIN+ & $2006-2100$ \\
\hline
\end{tabular}

first-order assessment of the OA impacts discussed in Sect. 2 on the future climate.

The reference simulation (REF), refers to the standard BGC formulation with no OA impacts. With this ocean BGC formulation, the ESM simulates the years 1850 to 2100 using historical atmospheric $\mathrm{CO}_{2}$ for 1850 to 2005 and then the RCP8.5 emissions until the year 2100. All of the remaining experiments to be discussed were started from the year 2006 and use the same RCP8.5 emissions as the REF simulation. In the REF simulation, the ratio of exported PIC to POC $\left(r^{\circ}\right)$ was kept constant, which implies the simulation includes a temperature effect on PIC production because the PIC production would increases as a warming ocean increases POC production (Pinsonneault et al., 2012; Schmittner et al., 2008).

The first $\mathrm{OA}$ simulation $(\mathrm{EP}+)$ considers the impact of rising $\mathrm{CO}_{2}$ on the $\mathrm{C} / \mathrm{P}$ ratio of the exported POC. The $\mathrm{C} / \mathrm{P}$ changes are based on (Oschlies et al., 2008), while the $\mathrm{C} / \mathrm{O}$ of POC and the PIC export remain unchanged. The modified POC export $\left(Q_{\mathrm{POC}}^{C}\right)$ is given by the following equations, where $\mathrm{CO}_{2}$ is the atmospheric $\mathrm{CO}_{2}$ concentration, $Q_{\mathrm{POC}}^{P}$ is the phosphate uptake in the photic zone and $\Delta z$ is the depth of the photic zone.

$Q_{\mathrm{POC}}=106 Q_{\mathrm{POC}}^{P} F_{\mathrm{o}} \Delta z$

$F_{\mathrm{O}}=1+\left(\mathrm{CO}_{2}-380\right) \cdot 2.3 / 700 / 6.6$, for $\mathrm{CO}_{2}>380$

At the start of the experiment (2006), the atmospheric $\mathrm{CO}_{2}$ equals $380 \mathrm{ppm}$ and the scaling factor $\left(F_{\mathrm{O}}\right)$ is equal to $1(\mathrm{C} / \mathrm{N}$ $=6.6$ ), which is the value used in the REF experiment. At the end of the experiment (2100), the atmospheric $\mathrm{CO}_{2}$ equals $1010 \mathrm{ppm}$ and the scaling factor $\left(F_{\mathrm{o}}\right) 1026(\mathrm{C} / \mathrm{N}=1.32)$.

In the second $\mathrm{OA}$ experiment (EP++), in addition to the $\mathrm{EP}+$ modification, the export of $\mathrm{POC}$ is prescribed to increase as atmospheric $\mathrm{CO}_{2}$ levels rise, reflecting the enhanced production due to enhanced photosynthesis with increased $\mathrm{CO}_{2}$. In addition, the PIC export $\left(Q_{\mathrm{PIC}}^{C}\right)$ is prescribed to decline as calcification decreases with rising $\mathrm{CO}_{2}$ (Ridgwell et al., 2009). To achieve this we increase the POC export scaling factor ( $S_{\text {npp }}$ Eq. A6, see Appendix), which increases POC export and reduces the rain ratio between PIC and POC export $(r)$ with atmospheric $\mathrm{CO}_{2}$ as follows:

$S_{\mathrm{npp}}=S_{\mathrm{npp}}^{\mathrm{o}}\left[4.5 \cdot\left(\mathrm{CO}_{2} / 380\right)-3.5\right]$
$Q_{\mathrm{PIC}}=r 106 Q_{\mathrm{POC}}^{P} \Delta z$
$r=r^{\mathrm{o}} \cdot 1 /\left(9.5 \cdot \mathrm{CO}_{2} / 380-8.5\right)$,

where $S_{\mathrm{npp}}^{\mathrm{o}}$ and $r^{\mathrm{o}}$ are the values used in the REF and the RCP8.5 experiments. At an atmospheric $\mathrm{CO}_{2}$ level of $1140 \mathrm{ppm}$ (the approximate value in our REF simulation at 2100) the POC export scaling factor is 10 times and the rain ratio is $5 \%$ of the REF experiment. Note that while the scaling factor was increased by 10 times, the actual increase in export of POC was still constrained by the availability of phosphate and light, which dramatically reduces the increase in POC export in this experiment.

In the third OA simulation (REMIN+), the standard BGC formulation was used but both the remineralisation of POC and the dissolution of PIC are enhanced. The increased POC remineralisation reflects an increasing rate of microbial activity with OA. The increased PIC dissolution reflects the impact of OA on the chemical dissolution of PIC. In the previously discussed experiments, POC and PIC have prescribed depth profiles (see A18 and A19 in Appendix), which are now modified by the atmospheric $\mathrm{CO}_{2}$ as follows to give an upper bound estimate of the potential impact of increased POC remineralisation and increased PIC dissolution on carbon storage in the ocean.

REMINPOC $=$ REMIN $_{\mathrm{POC}}^{\mathrm{o}}\left[1+\left(\mathrm{CO}_{2}-380\right) / 500\right]$
$\operatorname{REMIN}_{\mathrm{PIC}}=\mathrm{REMIN}_{\mathrm{PIC}}^{\mathrm{o}} 1 /[1+(\mathrm{CO} 2-380) / 500]$

The equations above give the factors used to modify the prescribed depth profiles for POC and PIC from the REF 
experiment, where $\mathrm{REMIN}_{\mathrm{POC}}^{o}=-0.9$ and $\mathrm{REMIN}_{\mathrm{PIC}}^{\mathrm{o}}=$ 3500 in the REF simulation (see equations A18 and A19). With an atmospheric $\mathrm{CO}_{2}$ level of $1000 \mathrm{ppm}$, the depth of remineralisation declines by 2.25 from the REF experiment.

For POC, this means the POC that sinks below $200 \mathrm{~m}$ declines from $54 \%$ in REF simulation to $25 \%$. For PIC, the PIC sinking below $1000 \mathrm{~m}$ reduces from $75 \%$ in REF simulation to $37 \%$.

These BGC changes are an idealised representation of the $\mathrm{OA}$ impact on the ocean BGC cycle. They were deliberately chosen to provide extreme perturbations to the BGC cycle and to test the potential for these impacts to have a significant consequence on the future projected climate.

\section{Results and discussion}

We will first present and discuss the REF simulation by assessing its present-day ocean state and its projected response to the RCP8.5 emission scenario. Then, we will project and discuss how OA impacts the ocean BGC cycle, and how this in turn impacts the future atmospheric $\mathrm{CO}_{2}$ concentration and climate.

\subsection{Historical period}

For the historical period, the simulated global surface warming generally agrees with the observed warming. The observed global surface temperature increase between 1850 1899 and $2001-2005$ is $0.76 \pm 0.19 \mathrm{~K}$ (Trenberth et al., 2007) compared to the simulated increase of $0.57 \pm 0.07 \mathrm{~K}$ (Zhang et al., 2014). The observed land surface temperature increase from 1850-1899 to 2001-2005 is $1.0 \pm 0.25 \mathrm{~K}$ (Brohan et al., 2006) compared to a simulated increase of $0.75 \pm 0.06 \mathrm{~K}$ (Zhang et al., 2014).

(Zhang et al., 2014) assessed the simulated anthropogenic $\mathrm{CO}_{2}$ uptake by the land and ocean, and showed that over the historical period the model realistically reflected the observed estimates. From 1850 to 2005, the total carbon accumulated in the land biosphere is $85 \mathrm{PgC}$, which is within the estimated land carbon uptake of $135 \pm 85 \mathrm{PgC}$ calculated from the estimated rates of ocean carbon uptake and atmospheric growth (Zhang et al., 2014). The simulated carbon accumulated in the ocean $(118 \mathrm{PgC})$ agrees with the estimated anthropogenic carbon storage in the ocean of $135 \pm 25 \mathrm{Pg}$ C (Khatiwala et al., 2009). (Zhang et al., 2014) also showed that simulated land and ocean carbon uptakes are consistent with the latest synthesis for the period 1960 to 2005 (Canadell et al., 2007).

To assess the realism of the ocean carbon simulation we compare (1) dissolved oxygen at $500 \mathrm{~m}$; (2) surface aragonite saturation state (3) aragonite lysocline depth; (4) the surface phosphate; (5) global alkalinity; (6) global preindustrial dissolved inorganic carbon; (7) global phosphate; (8) global oxygen; and (9) global apparent oxygen utilisation (AOU)

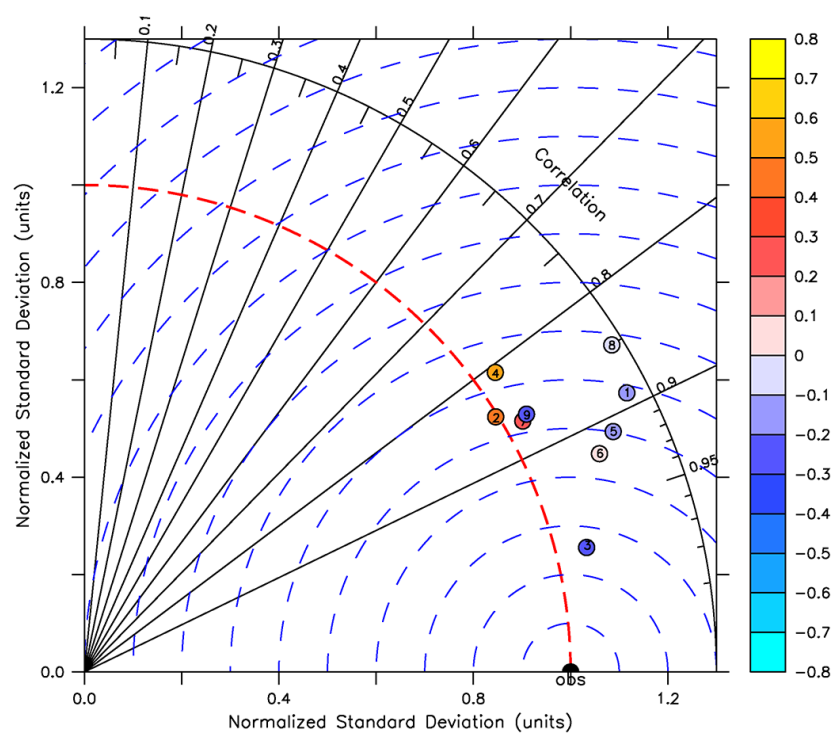

Figure 1. Taylor diagram of the comparison of the simulated fields with the observations for surface phosphate (1), dissolved oxygen at $500 \mathrm{~m} \mathrm{(2),} \mathrm{surface} \mathrm{aragonite} \mathrm{saturation} \mathrm{state} \mathrm{(3),} \mathrm{lysocline} \mathrm{depth}$ (4), and the three-dimensional fields of alkalinity (5), preindustrial dissolved inorganic carbon (6), dissolved oxygen (7), phosphate (8) and apparent oxygen utilisation (9). The observations are based on (Key et al., 2004) and (Boyer et al., 2009); the REF 1995 simulated fields are used for the comparison except for preindustrial inorganic carbon, which comes from the REF simulation in 1850. The colour bar gives the bias in the simulated fields normalised by the standard deviation in the observed fields. The plotted data are summarised in Table 3.

with the observations (Key et al., 2004; Boyer et al., 2009) using a Taylor (2001) (Fig. 1). We use the Taylor diagram to provide a quantitative assessment of the simulated fields, and the statistics shown in the Taylor diagram are summarised in Table 3. For visual comparisons of the simulation with observations see the Appendix; where, zonally averaged sections of alkalinity and preindustrial dissolved organic carbon (Fig. A1), along with global averaged profiles of alkalinity, preindustrial dissolved organic carbon, phosphate, oxygen and apparent oxygen utilisation (Fig. A2) are shown.

For dissolved oxygen at $500 \mathrm{~m}$, the REF simulation is highly correlated with the observations $(r=0.85)$ (Fig. 1 and Table 3 ), but overestimates the average oxygen concentration at $500 \mathrm{~m}\left(33 \mathrm{mmol} \mathrm{m}^{-3}\right)$. In general, the simulated dissolved oxygen levels at mid-depths are overestimated, but the simulated thickness of suboxic water (defined as oxygen concentrations less than $5 \mathrm{mmol} \mathrm{m}^{-3}$ ) was greater than observed (Fig. 2a and b). The simulated three-dimensional dissolved oxygen concentrations are highly correlated with observations $(r=0.87)$, consistent with what was shown at $500 \mathrm{~m}$, the simulated global averaged dissolved oxygen concentration is $19 \mathrm{mmol} \mathrm{m}^{-3}$ greater than the observed. The simulated excess in oxygen is associated with a simulated global averaged AOU concentration, which is $17 \mathrm{mmol} \mathrm{m}^{-3}$ 
Table 3. Summary statistics of the comparison of the REF simulated fields with the observations shown in Fig. 1. All simulated fields are based on the REF 1995 values except for preindustrial dissolved inorganic carbon which comes from the REF 1850 simulation fields.

\begin{tabular}{|c|c|c|c|c|c|c|c|c|}
\hline \multirow[b]{2}{*}{ Field } & \multirow[b]{2}{*}{$\begin{array}{l}\text { Observed } \\
\text { average }\end{array}$} & \multirow[b]{2}{*}{$\begin{array}{l}\text { Simulated } \\
\text { average }\end{array}$} & \multicolumn{6}{|c|}{ Observations versus REF simulation in 1995} \\
\hline & & & $\begin{array}{c}\text { Observed } \\
\sigma\end{array}$ & Mean error & $\begin{array}{l}\text { Normalis } \\
\text { RMS' }\end{array}$ & RMS & $\sigma$ & $\begin{array}{c}\text { Correlation } \\
\text { coefficent }\end{array}$ \\
\hline $\begin{array}{l}\text { Phosphate } \\
\text { at } 0 \mathrm{~m} \\
\left(\mathrm{mmol} \mathrm{m}^{-3}\right)\end{array}$ & 0.51 & 0.44 & 0.49 & -0.13 & 0.58 & 0.60 & 1.25 & 0.89 \\
\hline $\begin{array}{l}\text { Oxygen } \\
\text { at } 500 \mathrm{~m} \\
\left(\mathrm{mmol} \mathrm{m}^{-3}\right)\end{array}$ & 157.6 & 190.1 & 81.0 & 0.40 & 0.54 & 0.68 & 1.0 & 0.85 \\
\hline $\begin{array}{l}\text { Aragonite } \\
\text { saturation state } \\
\text { at } 0 \mathrm{~m}\end{array}$ & 2.97 & 2.75 & 0.85 & -0.29 & 0.26 & 0.39 & 1.06 & 0.97 \\
\hline $\begin{array}{l}\text { Lysocline } \\
\text { depth (m) }\end{array}$ & 1024 & 1407 & 679 & 0.56 & 0.63 & 0.84 & 1.04 & 0.81 \\
\hline $\begin{array}{l}\text { 3-D Alkalinity } \\
\left(\mathrm{mmol} \mathrm{m}^{-3}\right)\end{array}$ & 2418.1 & 2418.1 & 44.2 & 0.0 & 0.45 & 0.45 & 1.15 & 0.92 \\
\hline $\begin{array}{l}\text { 3-D preindustrial } \\
\text { DIC }\left(\mathrm{mmol} \mathrm{m}^{-3}\right)\end{array}$ & 2299.8 & 2285.6 & 93.8 & -0.15 & 0.50 & 0.52 & 1.19 & 0.91 \\
\hline $\begin{array}{l}\text { 3-D Phosphate } \\
\left(\mathrm{mmol} \mathrm{m}^{-3}\right)\end{array}$ & 2.09 & 2.09 & 0.67 & 0.00 & 0.68 & 0.68 & 1.28 & 0.85 \\
\hline $\begin{array}{l}\text { 3-D Oxygen } \\
\left(\mathrm{mmol} \mathrm{m}^{-3}\right)\end{array}$ & 172.4 & 191.6 & 64.5 & 0.29 & 0.52 & 0.60 & 1.04 & 0.87 \\
\hline $\begin{array}{l}\text { 3-D AOU } \\
\left(\mathrm{mmol} \mathrm{m}^{-3}\right)\end{array}$ & 146.9 & 129.3 & 68.0 & -0.26 & 0.54 & 0.60 & 1.05 & 0.86 \\
\hline $\begin{array}{l}\text { Thickness of } \\
\text { suboxic water (m) }\end{array}$ & 8.4 & 35.5 & 70.0 & 0.39 & 2.48 & 2.51 & 2.68 & 0.38 \\
\hline
\end{tabular}

less than observed (Table 3). While the simulated threedimensional AOU concentrations are highly correlated with the observations ( $r=0.86$ ), (Duteil et al., 2013) showed that this model has a mid-depth AOU maximum in the Pacific that is too small. This implies that the simulation is either over-ventilating the Pacific intermediate waters, or underestimating the remineralisation of $\mathrm{POC}$ in the ocean interior.
For surface phosphate, the REF simulation is highly spatially correlated with the observations $(r=0.89)$ (Fig. $2 \mathrm{c}$ and d), but has slightly greater spatial variability and slightly less surface phosphate than observed (Fig. 1 and Table 3). The REF-simulated three-dimensional phosphate concentrations are also highly correlated with the observations $(r=0.87)$ with spatial variability that is slightly greater than observed (Fig. 1 and Table 3). (Duteil et al., 2012) showed that of all the models they considered in their study, this model has the smallest error in preformed phosphate concentrations, with its ratio of preformed to total phosphate in the ocean interior (0.6) being only slightly less than observed (0.64). In the Pacific and Atlantic sections, (Duteil et al., 2012) showed that this model slightly underestimated the regenerated phosphate concentrations, implying that the low global AOU values reflect the underestimation of POC remineralisation in the ocean interior. 

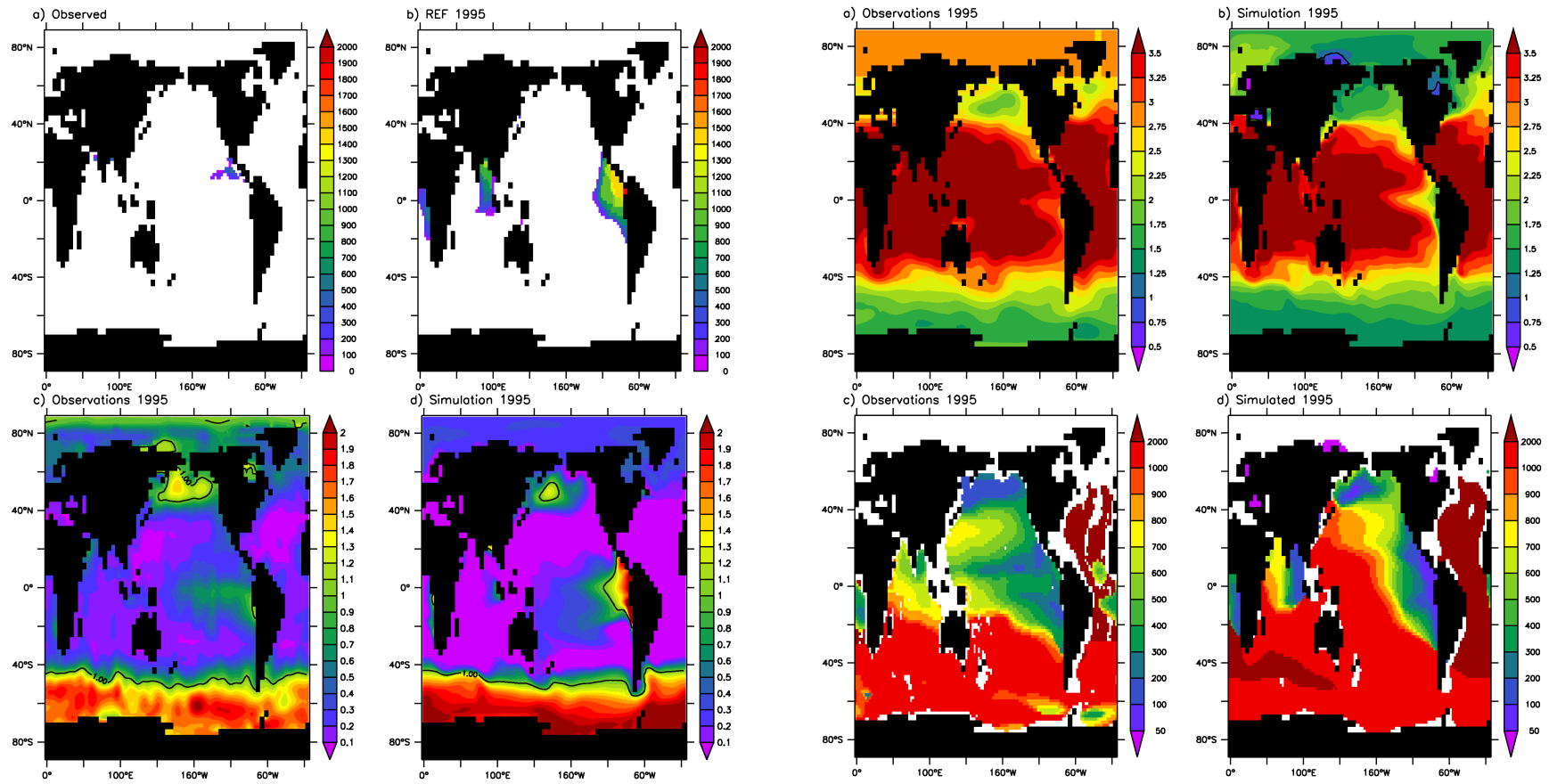

Figure 2. Annual mean for the year 1995 comparison of the observed and simulated fields for $(\mathbf{a}, \mathbf{b})$ thickness of suboxic layer $(\mathrm{m})$, and $(\mathbf{c}, \mathbf{d})$ surface phosphate concentration $\left(\mathrm{mmol} \mathrm{m}^{-3}\right)$. The suboxic waters are characterised by oxygen concentrations less than $5 \mathrm{mmol} \mathrm{m}^{-3}$ ). The observed aragonite saturation was calculated using Key et al. (2004) and Boyer et al. (2009) gridded datasets.

For surface aragonite saturation state, the REF simulation was highly correlated with the aragonite saturation state calculated from the observations (Key et al., 2004), with the simulation slightly underestimating the average saturation state (Fig. 3 and Table 3).

In the ocean interior, the REF simulation has a similar pattern of the aragonite lysocline to that observed. In general, the simulated lysocline depth is a little deeper than observed, except in the western Pacific, where the simulated values are several hundred metres too deep (Fig. 3 and Table 3). For the simulated three-dimensional alkalinity and preindustrial dissolved inorganic carbon concentrations, the REF simulation is highly correlated with the observations ( 0.92 and 0.91 , respectively), whereas spatial variability slightly exceeds the observations with a mean dissolved inorganic carbon concentration that is $15 \mathrm{mmol} \mathrm{m}^{-3}$ less than observed (Table 3). The simulated global averaged dissolved inorganic carbon concentration that is less than observed is consistent with the underestimation of POC remineralisation in the ocean interior.

To assess the ocean circulation of the REF simulation, we use the analysis of (Matsumoto et al., 2004). They show the CSIRO model in their study, which is nearly identical to the REF simulation presented here, correctly ventilated the ocean on decadal and centennial timescales based on simu-

Figure 3. Annual mean for the year 1995 comparison of the observed and simulated fields for $(\mathbf{a}, \mathbf{b})$ surface aragonite saturation state (c, d) aragonite lysocline depth (m); and thickness of the suboxic layer $(\mathrm{m})$. The observations for aragonite saturation are calculated from (Key et al., 2004).

lated CFC-11, natural radiocarbon and anthropogenic carbon concentrations.

In summary, the REF simulation generally reflects the present-day ocean state (correlation coefficient with observations greater than 0.8). However, the important discrepancies with the observations are that the suboxic layer is too thick, the lysocline in the Western Pacific subtropical and equatorial water is too deep, and the remineralisation of POC in the ocean interior is less than observed. These model biases are considered when assessing the projected regional changes associated with OA.

\subsection{Future OA impacts on ocean BGC}

\subsubsection{Carbon climate feedbacks}

The addition of the OA impacts on the ocean BGC alters the atmospheric $\mathrm{CO}_{2}$ by less than $45 \mathrm{ppm}$ by 2100 (Fig. 4). Enhanced POC export increases ocean carbon uptake, and hence atmospheric $\mathrm{CO}_{2}$ drops by $43 \mathrm{ppm}$ at most by 2100 . While the enhanced remineralisation of the POC and increased dissolution of PIC reduces carbon uptake, and atmospheric $\mathrm{CO}_{2}$ increases by about $18 \mathrm{ppm}$ by 2100 . The combination of enhanced POC export in conjunction with the shoaling of POC remineralisation and PIC dissolution reduces atmospheric $\mathrm{CO}_{2}$ by $38 \mathrm{ppm}$. The atmospheric $\mathrm{CO}_{2}$ change in the $\mathrm{COMB}$ experiment is greater than the 

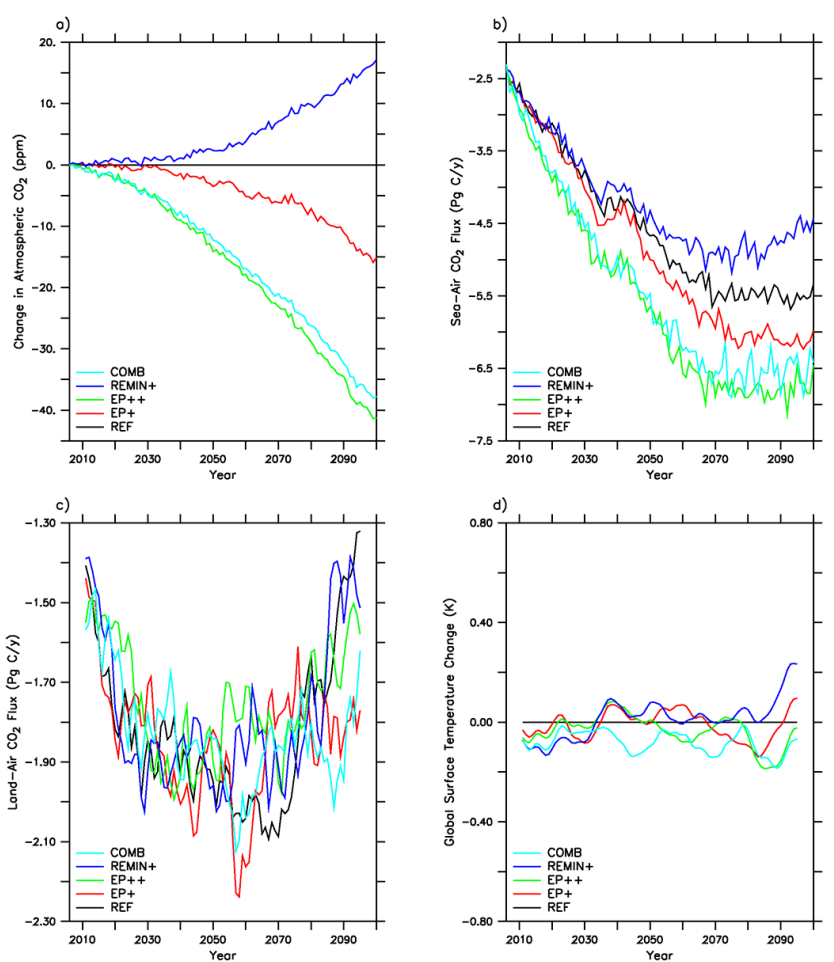

Figure 4. (a) Change in atmospheric $\mathrm{CO}_{2}$ (ppm) for the future period relative to the REF simulation for the various $\mathrm{OA}$ experiments (see Table 2 for a description of the experiments). (b) Simulated global ocean carbon uptake for the different OA experiments. (c) Simulated 10-year running mean of the land carbon uptake by the different OA experiments. (d) Simulated 10-year running mean of the change in global surface temperature relative to the REF simulation for the various OA experiments.

difference between EP++ and REMIN+ simulations because the combination of larger export with shallower recycling of POC is more efficient at storing carbon in the ocean than when the two changes are considered individually. For the global climate, the OA impacts of these small atmospheric $\mathrm{CO}_{2}$ changes leads to global surface temperature deviations of less than $0.25 \mathrm{~K}$ (Fig. 4).

\subsubsection{Changes in BGC fields}

While the OA impacts on the ocean carbon storage and climate by the end of this century are small, we investigate whether the BGC fields in the ocean are significantly altered by OA. Key ocean BGC fields that have been shown to be impacted by global warming and OA are aragonite saturation state, lysocline depth, export production, dissolved oxygen and volume of suboxic water. Here, we focus on how the OA impacts each of these fields relative to the REF simulation.
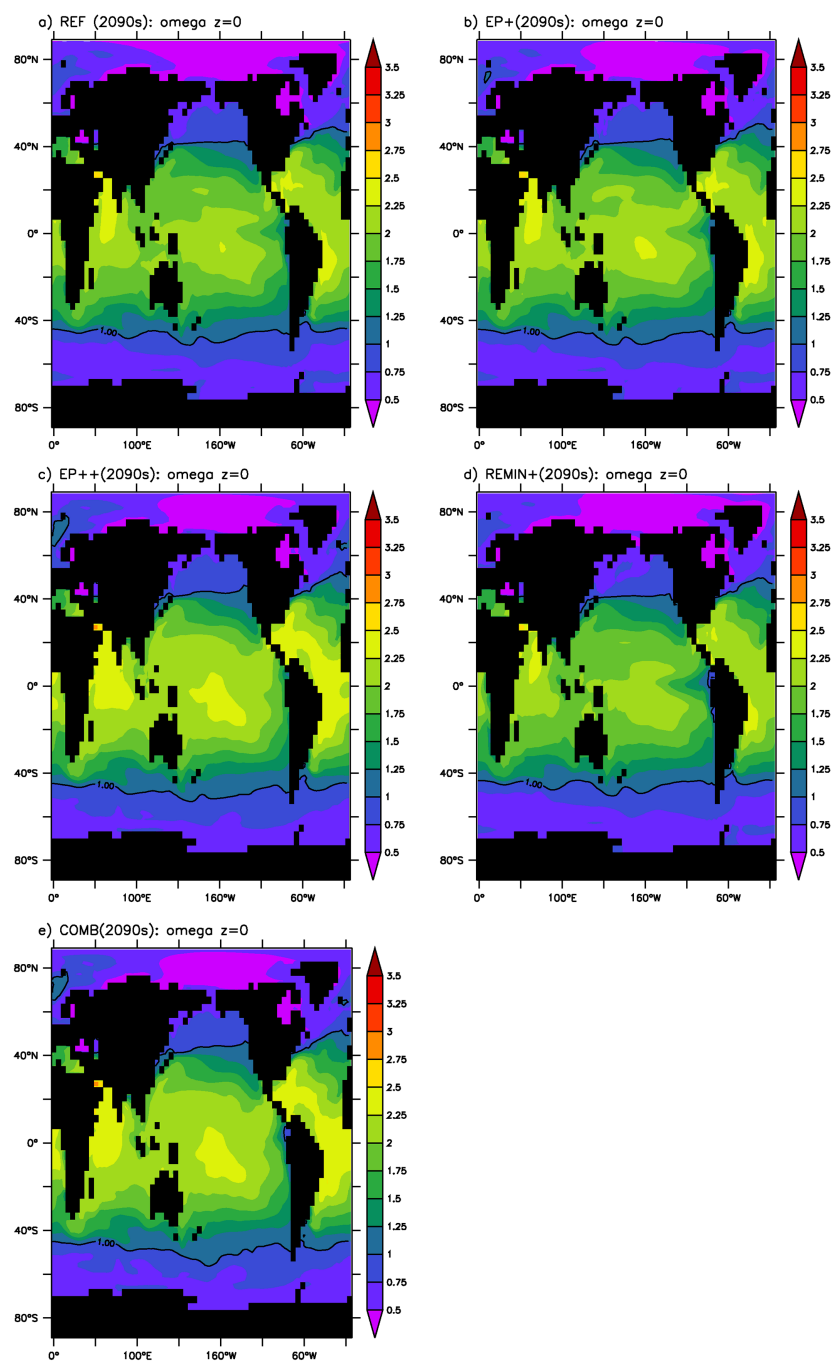

Figure 5. Annual mean surface aragonite saturation state during the 2090-2100 period for (a) REF; (b) EP+; (c) EP++; (d) REMIN+; and (e) COMB simulations.

\subsubsection{Aragonite saturation state}

For the surface aragonite saturation state, there are only subtle differences among the simulations (Fig. 5). As expected, all simulations show a dramatic reduction in the surface aragonite saturation state by 2100 , with the surface water poleward of approximately $40^{\circ} \mathrm{S}$ and $40^{\circ} \mathrm{N}$ being undersaturated with respect to aragonite (Fig. 5). By 2100, the REF simulation has an atmospheric $\mathrm{CO}_{2}$ value of $1026 \mathrm{ppm}$. At low latitudes, by 2100 the maximum aragonite saturation state from all simulations is less than 2.75 , which is a saturation state level in which historically no living corals are observed (Guinotte et al., 2003). In all simulations, the upwelling region of the eastern Equatorial Pacific shows a minimum in the tropical aragonite saturation state.

For aragonite lysocline depth, all simulations show a dramatic shoaling in the polar regions (Fig. 6). In all 

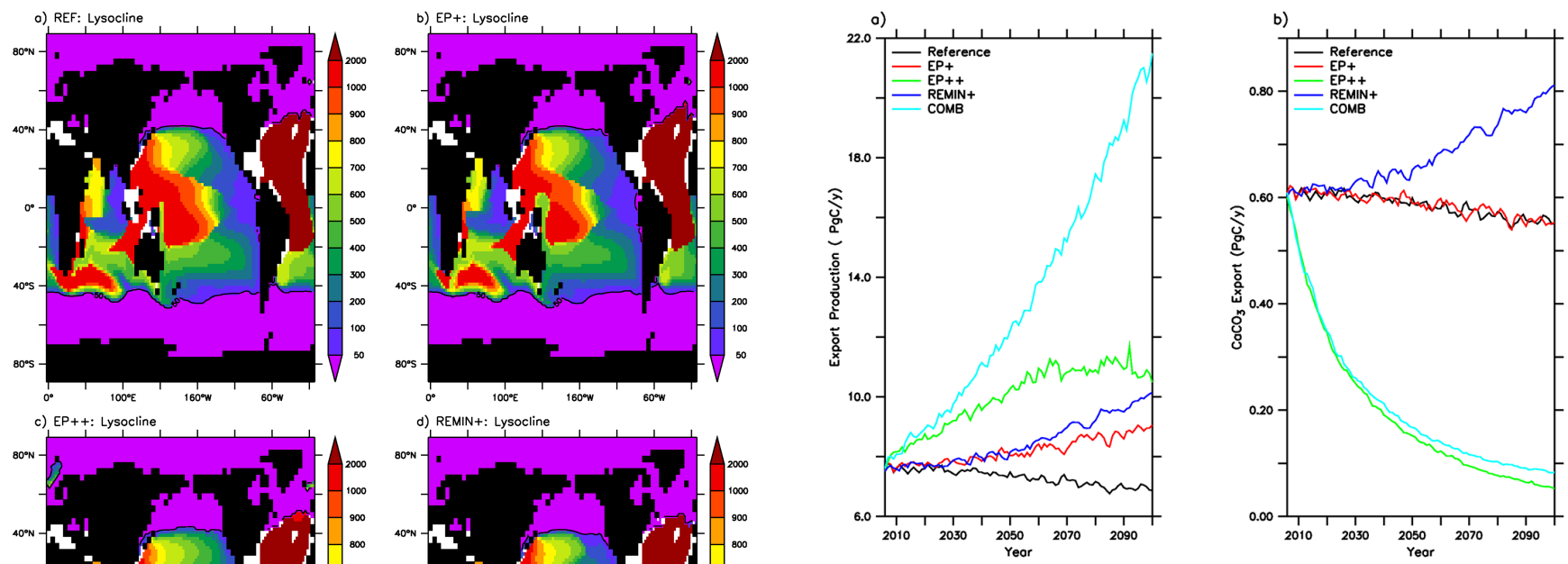

Figure 7. (a) Projected global export of POC from the upper $100 \mathrm{~m}$ of the ocean. (b) Projected global export of PIC from the upper $100 \mathrm{~m}$ of the ocean.

\subsubsection{Export production}

For the export of POC from the upper ocean, in the REF simulation shows a small global reduction (Fig. 7), which is mostly confined to the equatorial Pacific, Indian and North Atlantic oceans (Fig. 8) associated with increased upper ocean stratification that occurs in climate change projections (e.g. Matear and Hirst, 1999). The export of PIC from the upper ocean is also shown in Fig. 7, with all experiments showing a decline global export in the future except for REMIN+. In the REMIN+ simulation, the increase in POC export is associated with an increase in PIC export because the rain ratio was held constant. Interestingly, the different $\mathrm{OA}$ experiments show large regional differences in export production (Fig. 8), with EP++ and COMB substantially increasing export production in the Southern Ocean. However, for the global integrated value, all OA impacts cause an increase in POC export production, with the greatest increase occurring in the COMB projection.

The large range in the export production response to the ations, the eastern tropical and subtropical Pacific cline is less than $100 \mathrm{~m}$ deep. Similarly, all simulations show lysocline depths of less than $100 \mathrm{~m}$ in the Indian Ocean. It is only in the equatorial western Pacific that the lysocline depths remain greater than $1000 \mathrm{~m}$ by 2100 . Note that this is the region where the REF simulation overestimated the lysocline depth by several hundred metres, and in the OA experiments this region retains its resilience to change. This probably reflects a bias in the model, and we anticipate that the region would show much greater shoaling by the end of the century consistent with (Bopp et al., 2013).

Overall, the OA impacts only make subtle changes to the overall dramatic reduction in surface aragonite saturation state and lysocline depth projected with the RCP8.5 emission scenario. different OA experiments is consistent with previous studies (e.g. Tagliabue et al., 2011). The simulations reveal that OA impacts on export production are much greater than their impacts on climate change. Such behaviour demonstrates that the consequence of OA will not be through its impact on climate change, but on how it impacts the flow of energy in marine ecosystems. These changes may have significant impacts on marine ecosystems and their productivity, biodiversity, and our future ability to exploit them as a food resource.

\subsubsection{Dissolved oxygen}

While the OA impacts had only a small effect on atmospheric $\mathrm{CO}_{2}$ levels, the export production varied dramatically amongst the simulations (Fig. 8), which has the potential 

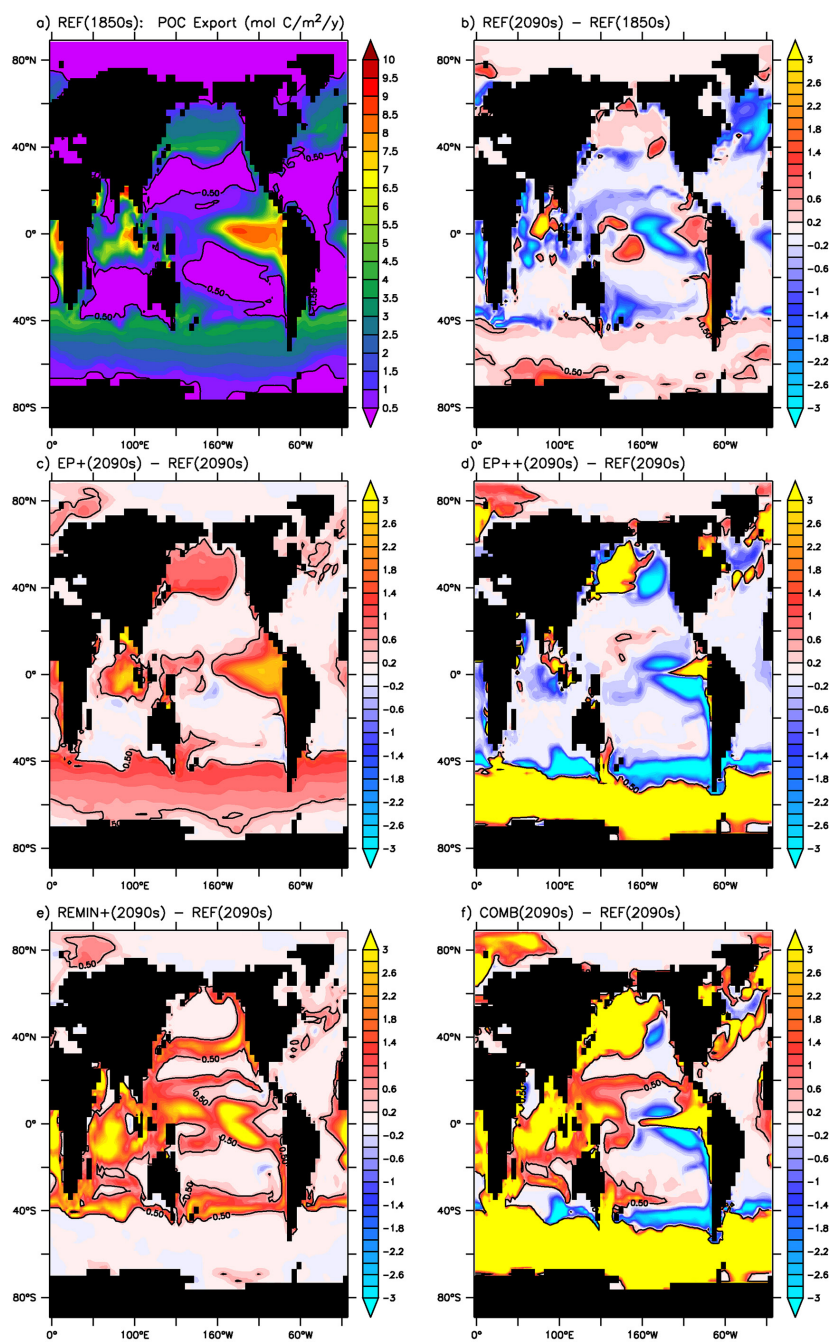

Figure 8. Export production ( $\mathrm{mol} \mathrm{C} \mathrm{m}^{-2} \mathrm{yr}^{-1}$ ) from the (a) REF in 1850; (b) the change in 2090-99 mean for REF relative to (a). For the 2090-2099 mean, the change relative to REF for (c) EP+; (d) $\mathrm{EP}++$; (e) REMIN+; (f) COMB simulations.

to alter dissolved oxygen levels in the ocean. With climate change, the REF simulation shows a decline in the mid-water dissolved oxygen levels in the North Pacific, equatorial Pacific and Southern oceans (Fig. 9).

The oceanic oxygen levels are expected to decline under global warming (e.g. Matear et al., 2000; Bopp et al., 2002), because surface warming lowers the sea surface oxygen concentrations, enhances stratification, reduces ventilation of the thermocline, and reduces thermohaline circulation, which all tend to decrease the supply of oxygen to the ocean interior. The reduced oxygen supply to the ocean interior is also linked to increased residence time of water at depth, thereby enhancing biological oxygen consumption in the ocean interior.
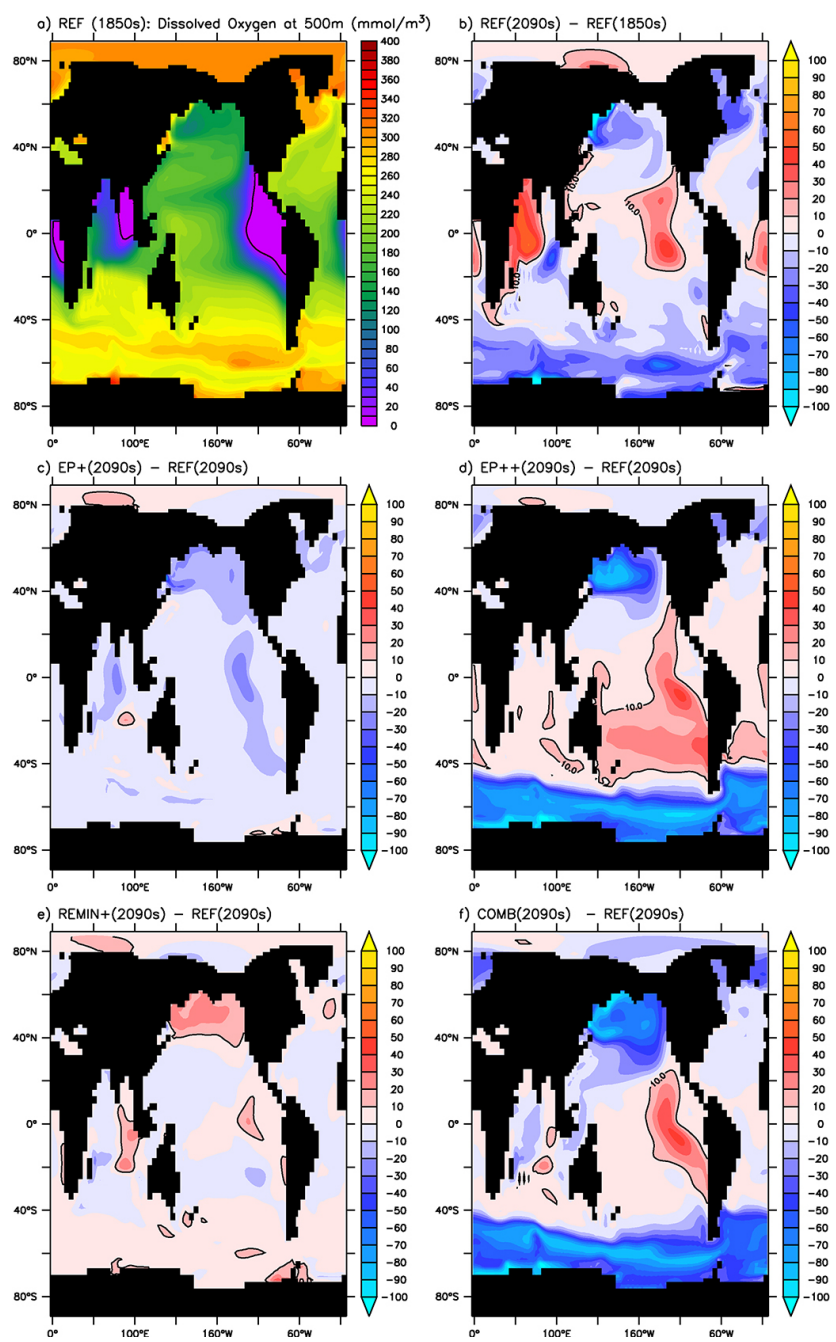

Figure 9. Dissolved oxygen $\left(\mathrm{mmol} \mathrm{m}^{-3}\right)$ at $500 \mathrm{~m}$ for (a) REF in 1850; (b) the change in 2090-2099 mean for REF relative to (a). For the 2090-99 mean, the change relative to REF for (c) EP+; (d) $\mathrm{EP}++$; (e) REMIN+; (f) COMB simulations.

The REF simulation projects a global decline in total dissolved oxygen inventory of $1.8 \%$ between 2006 and 2100 (Fig. 10b) and of $2.5 \%$ between 1850 and 2100 . The projected small decline is comparable to other ESM projections, which show a small decrease of $2 \%$ to $4 \%$ by the end of 2100 with climate change (Cocco et al., 2013). The decline in dissolved oxygen in the major ocean basins is also reflected in a change in the thickness of the suboxic water (defined as water with dissolved oxygen of less than $5 \mathrm{mmol} \mathrm{m}^{-3}$ ) (Fig. 10a). In the REF simulation, there is a projected $5 \%$ decline in suboxic water by 2100 (Fig. 10a). This is consistent with their multi-model analysis of CMIP5 (Cocco et al., 2013), which showed that the projected total volume of suboxic waters remain relatively unchanged $( \pm 5 \%)$ by the end of 2100 with climate change. As discussed by (Cocco et al., 2013), the projected oxygen changes in the upper $1000 \mathrm{~m}$ of 

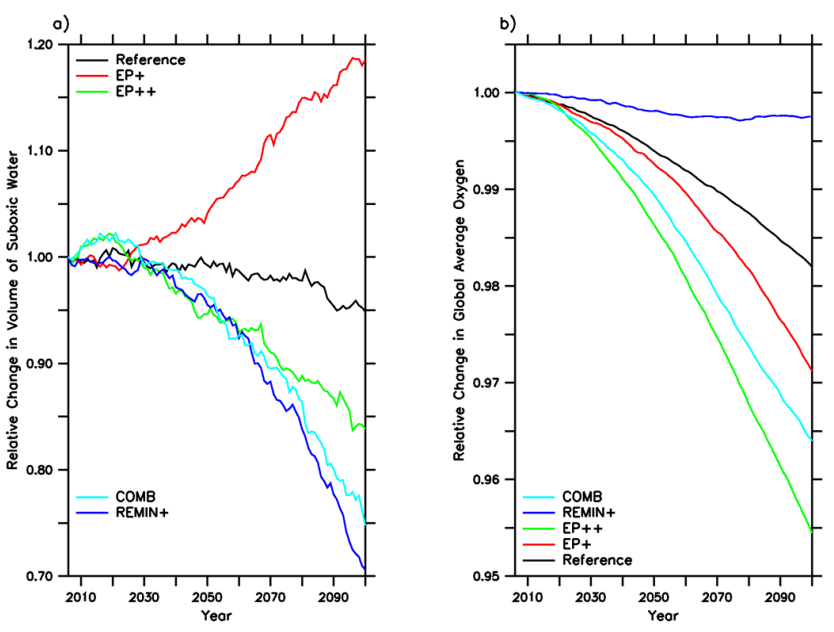

Figure 10. (a) The ratio of the simulated change in the volume of suboxic water to the simulated present-day (2006) value. (b) The ratio of the simulated change in the global ocean inventory of dissolved oxygen to the simulated 2006 value.

the ocean displays a complex regional pattern with both positive and negative trends reflecting the complex interactions between changes in circulation, biological production, biological remineralisation, and temperature.

The inclusion of OA impacts that could either increase POC export from the upper ocean (Fig. 7) and/or reduce its depth of remineralisation may substantially decrease oxygen levels in the ocean interior. For the total oxygen inventory in the ocean, the simulations reveal that increased POC export causes a decline in oxygen, while the shoaling of POC remineralisation has little impact (Fig. 10b).

The EP+ simulation showed a $17 \%$ increase in the thickness in the suboxic water by 2100 (Fig. 10a). Similar simulations where the $\mathrm{C} / \mathrm{N}$ ratio of exported POC matter is increased with OA project reduced dissolved oxygen levels in the ocean and a comparable increase in the volume of suboxic water to the EP+ projection (Oschlies et al., 2008; Tagliabue et al., 2011).

(Oschlies et al., 2008) shows the volume of suboxic water is very sensitive to small changes in the remineralisation of POC in the ocean interior. Our simulations confirm this result, but also show the volume of suboxic water is sensitive to the location where OA increases POC export. With the shoaling of POC remineralisation (REMIN+) there is a reduction in the volume of suboxic water. By confining POC remineralisation to the upper ocean, the equatorial Pacific has less suboxic water, because this water is now more influenced by air-sea gas exchange, there is a global decline in the volume of suboxic water (Fig. 10). Similarly, the EP++ simulation with increased export production shows the greatest decline in total oxygen inventory (Fig. 10b), but a decline in the volume of suboxic water by 2100 (Fig. 10a). The COMB simulation, with its increased POC export and shoaling of
POC remineralisation also projects a decline in the volume of suboxic water. However, the COMB simulation projects the development of suboxic zones in the North Pacific and Southern Ocean where the combination of increased export production, shoaling of depth of POC remineralisation, and increased stratification with global warming allows for the development of suboxic water in these regions.

By prescribing the POC depth profile in our model formulation, POC will be remineralised without consuming oxygen, which implies unconstrained denitrification. By having unlimited denitrification, the consumption of oxygen may be underestimated when POC export increases, because POC remineralisation occurs by denitrification rather than by oxygen consumption. Thus, the simulated response of the thickness of suboxic water to increasing POC export, as in the $\mathrm{EP}+$ and $\mathrm{COMB}$ simulations, may be underestimated.

Presently, the large uncertainty in the potential changes in POC export and remineralisation with OA makes it difficult to project the potential consequences of $\mathrm{OA}$ on dissolved oxygen levels with confidence, and this makes it a critical issue for further investigation. The response of denitrification to potential changes in POC export adds another uncertainty to projecting the future interior oxygen levels changes with $\mathrm{OA}$, warranting further study.

\section{Summary and perspectives}

Ocean acidification is the inevitable consequence of rising atmospheric $\mathrm{CO}_{2}$ occurring in conjunction with global warming. Published studies have hypothesised the potential of OA to impact biogeochemical cycling in the ocean. However, to date, no studies have combined these impacts to quantify the integrated impacts on ocean biogeochemistry and the feedbacks onto the future climate. Here, we explore the integrated consequences of these OA-induced changes using an ESM and some first-order representations of the potential OA impacts on marine biogeochemical cycles. A key result of this study is that OA does not significantly alter the total carbon stored in the ocean; the potential changes in atmospheric $\mathrm{CO}_{2}$ levels (45 ppm maximum) were small compared to the future concentration projected with the RCP8.5 emission scenario by the end of this century (more than $1000 \mathrm{ppm}$ ). The small impact on future atmospheric $\mathrm{CO}_{2}$ levels means the OA impacts will have only a minor feedback on projected global warming; our simulations suggest that by 2100 the global averaged surface temperature would be altered by less than $0.25 \mathrm{~K}$. Therefore, while the simulations do project significant global warming $(\approx 3 \mathrm{~K}$ by 2100 ), the inclusion of $\mathrm{OA}$ impacts on the marine BGC cycle did not significantly alter the projected changes. Consistent with both the small impact on carbon storage in the ocean and on global warming, the inclusion of OA impacts did not significantly alter the projected trajectory of future ocean acidification (e.g. surface aragonite state and lysocline depth). However, we emphasise 
that with the RCP8.5 scenario, by 2100 significant changes in OA are projected. All polar surface waters will be undersaturated with respect to aragonite, and the maximum surface aragonite saturation state in the tropics will be less than 2.75 , a value below which coral reefs are not historically found. Such changes are likely to have profound impacts on marine ecosystems.

Where OA has the potential to have a significant impact is on the POC and PIC export from the upper ocean. We emphasise the impacts of these changes on marine ecosystems are highly uncertain and needs further study. While deliberately conceived to be large, the changes in PIC and POC export did not significantly change the future depth of the lysocline, however, they did significantly change the regional export production and the interior oxygen levels.

The inclusion of OA impacts that could either increase POC export from the upper ocean or reduce its depth of remineralisation could substantially decrease oxygen levels in the ocean interior. However, the large variability in potential changes in POC export with OA, presently makes it difficult to confidently assess the consequences of $\mathrm{OA}$ on dissolved oxygen levels, and therefore this remains another important issue to address. The decline in oxygen with the rising $\mathrm{CO}_{2}$ is likely to have consequences for marine organisms with high metabolic rates. Global warming, lower oxygen and higher $\mathrm{CO}_{2}$ levels represent physiological stresses for marine aerobic organisms that may act synergistically with ocean acidification (Portner and Farrell, 2008). Understanding how OA and global warming impact marine organisms also warrants further investigation.

Our study has focused on the OA impacts on the BGC cycles and climate change only to the end of this century; however, anthropogenic changes in carbon and climate will persist for many centuries. (Schmittner et al., 2008) used an ESM to show that the ocean BGC had a positive feedback on atmospheric $\mathrm{CO}_{2}$ and climate that were important on multi-centennial to millennial timescales. In their simulations, changes in ocean biology ultimately became important to the ocean carbon uptake after the year 2600, and by the year 4000 the feedback by the ocean accounted for $320 \mathrm{ppm}(22 \%)$ of the atmospheric $\mathrm{CO}_{2}$ increase since the preindustrial period.

While our study focused on a subset of key BGC processes in the ocean that may modulate the oceanic uptake of $\mathrm{CO}_{2}$, other greenhouse gases and other BGC processes may be altered by OA, to put these in context. The following briefly reviews other potential OA impacts and attempts to quantify and compare them to our results.

The next two most important greenhouse gases produced in the ocean are methane $\left(\mathrm{CH}_{4}\right)$ and nitrous oxide $\left(\mathrm{N}_{2} \mathrm{O}\right)$, and in the ocean their production is linked to the remineralisation of organic matter in low-oxygen water (Matear et al., 2010; Gruber and Galloway, 2008). The decline in the interior oxygen levels should be associated with increased production of both these gases (Glessmer et al., 2009).
(Schmittner et al., 2008) used an ESM climate change projection run until the year 4000 to show that a tripling of the volume of suboxic water doubled $\mathrm{N}_{2} \mathrm{O}$ production in the ocean, increased the atmospheric concentrations by $60 \mathrm{ppb}$, leading to a warming of about $0.25 \mathrm{~K}$, a relatively small change given the length of their simulation.

Enhanced dinitrogen $\left(\mathrm{N}_{2}\right)$ fixation by cyanobacteria occurs under elevated $p \mathrm{CO}_{2}$ concentrations (Hutchins et al., 2009). This provides an increased source of reactive nitrogen (N) that has the potential to increase primary production in the oligotrophic tropical and subtropical areas. However, this response is limited, as the relieving of $\mathrm{N}$ limitation will ultimately lead to phosphate limitation, which will also limit the potential carbon uptake. Ocean-only simulations where sufficient $\mathrm{N}$ was added to remove nitrate limitation gave a maximum reduction in atmospheric $\mathrm{CO}_{2}$ of about $22 \mathrm{ppm}$ by 2100 (Matear and Elliott, 2004). Again, it is a small effect when compared to the future atmospheric value associated with the RCP8.5 emissions scenario.

Iron is a biologically important element, and therefore any change in its bioavailability has the potential to change the growth rate of phytoplankton. At present there is little consensus on the sign of this change with OA. A slower iron uptake by diatoms with OA is seen in experiments with Atlantic surface water (Shi et al., 2010), while an increase has been reported in coastal waters (Breitbarth et al., 2010). If we assume OA can increase the bioavailability of iron sufficiently to remove iron limitation on phytoplankton growth, we can use previous ocean model simulations to quantify the maximum potential increase in carbon storage. Such studies showed that this process alone could increase carbon storage in the ocean and reduce atmospheric $\mathrm{CO}_{2}$ by 33 to $80 \mathrm{ppm}$ by 2100 (Aumont and Bopp, 2006; Matear and Wong, 1999). While it is a larger response than what we project with our OA experiments, this is an upper bound that does not mechanistically link OA to the bioavailability of iron. Even this upper bound estimate is small in comparison to the atmospheric $\mathrm{CO}_{2}$ projected with the $\mathrm{RCP} 8.5$ emissions scenario by 2100 $(\approx 1000 \mathrm{ppm})$, hence it would only have a minor impact on the future climate.

Further, iron is only one of many biologically important trace metals, for which bioavailability will change in response to OA (Hoffmann et al., 2012) and potentially alter biological production. Therefore, more studies are required to understand how changes in the bioavailability of trace metals in response to OA may impact future biological production.

The ocean is also a source of climatically active trace gases to the atmosphere such as dimethyl sulphide (DMS), which can alter cloud properties. DMS is a gaseous sulphur compound produced by marine biota in surface seawater (Gabric et al., 1993). The marine production of DMS provides $90 \%$ of the biogenic sulfur in the marine atmosphere, and in the atmosphere it is rapidly oxidised to produce particles that can affect cloud formation and climate (Arnold et al., 2013). The effects of increasing anthropogenic $\mathrm{CO}_{2}$ and the resulting 
warming and OA on trace gas production in the oceans remains poorly understood.

Modelling studies vary substantially in their predictions of the change in DMS emissions with climate change. Elevating $\mathrm{CO}_{2}$ without any other environmental changes suggest a significant decrease in the future concentration of DMS (Hopkins et al., 2011). However, studies in polar waters suggested increases in DMS emission ranging from $30 \%$ to more than $150 \%$ (Cameron-Smith et al., 2011; Kloster et al., 2007; Gabric et al., 2011) by 2100 with only climate change. While a recent ESM study by (Six et al., 2013) projected a global decrease in DMS production of $18 \pm 3 \%$ by 2100 , with $83 \%$ of this change attributed to OA, leading to only a modest equilibrium warming of 0.23 to $0.48 \mathrm{~K}$. (Six et al., 2013) simulated strong regional responses of increasing (polar regions) and decreasing DMS emissions, which reflected the combined affect of increased net primary production and regional shifts in community composition. Therefore, more studies combining the impacts of global warming and OA on marine DMS production are warranted to better determine its regional response and sign, particularly at the marine species and ecosystem levels.
Potential climate-carbon feedbacks of OA and global warming appear small relative to the input of carbon into the atmosphere by human activity under the RCP8.5 scenario. However, understanding and projecting the combined OA and global warming impact on marine ecosystems remains the outstanding issue to tackle. In particular, biological production may change with the projected OA, and the potential consequences for marine organisms and ecosystems are poorly known. 


\section{Appendix A: Ocean Biogeochemical Model Equations}

The ocean BGC module is based on (Matear and Hirst, $2003)$, and simulates the evolution of phosphate $(\mathrm{P})$, oxygen $(\mathrm{O})$, carbon $(\mathrm{C})$ and alkalinity $(\mathrm{A})$ in the ocean. The BGC module includes a simple representation of the surface export production of biological matter as a function of the temperature, mixed-layer depth, and nutrient concentration (phosphate) in the euphotic zone, with the sinking particulate organic matter (POM) and particulate inorganic carbon (PIC) remineralising according to prescribed functions of depth. The euphotic zone production of organic matter consumes dissolved phosphorous, nitrogen and carbon and releases oxygen according to the (Redfield, 1934) ratio $\mathrm{P}: \mathrm{N}: \mathrm{C}: \mathrm{O}_{2}$ of $1: 16: 106:-138$, while the subsurface remineralisation conversely releases/consumes these elements in like ratio. While nitrogen is not explicitly modelled, we include its ratio to $\mathrm{P}$ and $\mathrm{C}$ to make it clear how processes like denitrification affect the modelled $\mathrm{P}$ and $\mathrm{C}$ tracers. The following briefly summarises how the BGC processes are parameterised and how they affect the BGC tracers. For reference, we give here the conservation equation for dissolved inorganic carbon concentration $(C)$ :

$$
\begin{aligned}
& \frac{\partial C}{\partial t}=-\nabla_{3}(u C)+\nabla_{I}\left(K_{I} \nabla_{I} C\right) \\
& +\frac{\partial}{\partial z}\left(K_{v} \frac{\partial C}{\partial z}\right)+Q_{F}^{C}-Q_{O}^{C}-Q_{I}^{C}
\end{aligned}
$$

The first term on the right represents the usual threedimensional advection, the second term represents diffusion along the neutral density surfaces, and the third term represents vertical diffusion. $Q_{O}^{C}$ denotes the biological production and consumption of particulate organic carbon. $Q_{I}^{C}$ denotes the production and dissolution of particulate inorganic carbon. The carbon dioxide flux into the surface ocean across the air-sea interface $\left(Q_{F}^{C}\right)$ is given by

$Q_{F}^{C}=K\left(p \mathrm{CO}_{2}^{\text {atmosphere }}-p \mathrm{CO}_{2}^{\text {ocean }}\right)$,

where $K$ is the gas exchange coefficient, which is a function of wind speed and temperature (Wanninkhof, 1992), $p \mathrm{CO}_{2}^{\text {atmosphere }}$ is the atmospheric partial pressure of carbon dioxide (as simulated by the model), and $p \mathrm{CO}_{2}^{\text {ocean }}$ is the partial pressure carbon dioxide in the surface ocean water. $p \mathrm{CO}_{2}^{\text {ocean }}$ is computed from the surface temperature, salinity, dissolved inorganic carbon concentration and alkalinity using the OCMIP2 carbon chemistry routine (Najjar et al., 2007). A similar equation is used for air-sea oxygen exchange, where the atmospheric partial pressure of oxygen $\left(p \mathrm{O}_{2}^{\text {atmosphere }}\right)$ is fixed at $0.2048 \mathrm{~atm}$ (Weiss, 1970), and $p \mathrm{O}_{2}^{\text {ocean }}$ is the effective partial pressure oxygen in the surface ocean water computed from the simulated surface oxygen concentration divided by the oxygen concentration in equilibrium with the atmosphere multiply by $p \mathrm{O}_{2}^{\text {atmosphere }}$. For alkalinity and phosphate there is no air-sea flux term.
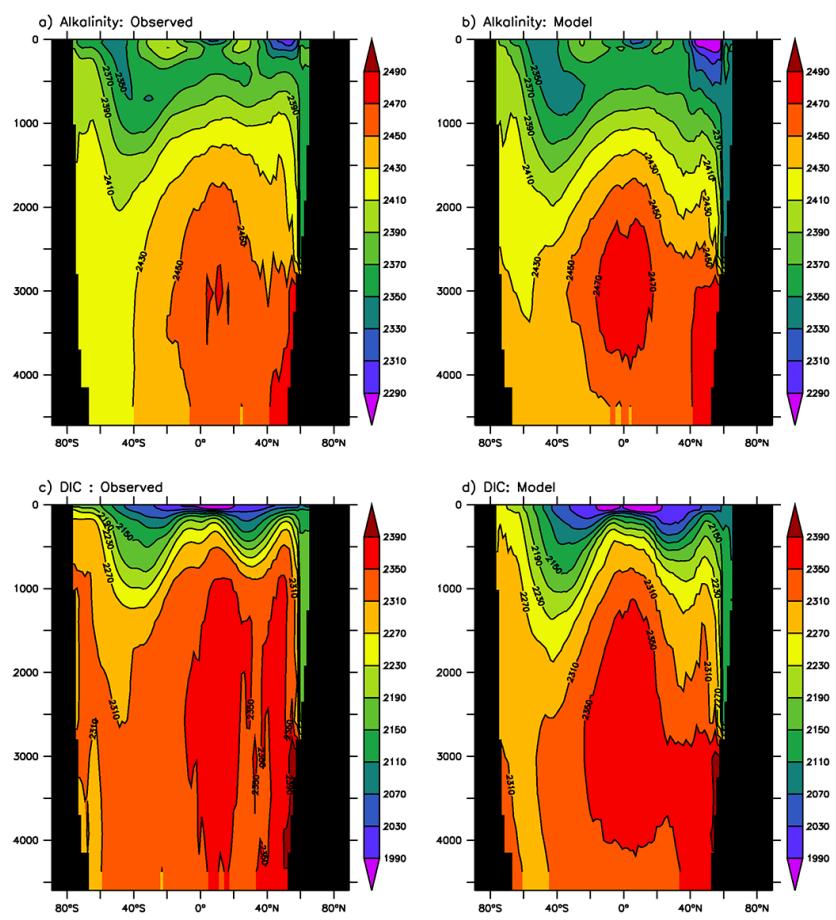

Figure A1. Comparison of the observed alkalinity (a) and preindustrial dissolved inorganic carbon (c) (Key et al., 2004) with the REF simulation in the year 1850 for alkalinity (b) and dissolved inorganic carbon (d) in units of $\mathrm{mmol} \mathrm{m}^{-3}$.

In the photic zone, which is set to be the surface layer of the model (upper $50 \mathrm{~m}$ ), the biological production of particulate organic matter and particulate inorganic carbon occurs. For particulate organic matter, the production of particulate organic phosphorus (POP) was defined by the following equations:

$$
\begin{aligned}
V_{\max } & =0.6(1.066)^{T} \\
F(I) & =\left[1-e^{G(I)}\right] \\
G(I) & =\frac{I(x, t) \alpha \mathrm{PAR}}{V_{\max }} \\
Q_{O}^{P} & =S_{\mathrm{npp}}^{\mathrm{o}} V_{\max } \operatorname{Min}\left[\frac{P}{P+P_{k}}, F(I)\right] \\
E_{\mathrm{POP}} & =Q_{O}^{P} \Delta z
\end{aligned}
$$

$V_{\max }$ is the maximum growth rate in day ${ }^{-1}$, which is a function of the surface layer temperature $\left(T,{ }^{\circ} \mathrm{C}\right) . F(I)$ is the productivity versus irradiance equation used to describe phytoplankton growth, which is given as a unitless value and provides a measure of light-limited growth. $G(I)$ a unitless function of the light availability for growth, which is calculated from the daily averaged incident shortwave radiation $(I)$ in $\mathrm{W} \mathrm{m}^{-2}$, the fraction of shortwave radiation that is photosynthetically active PAR (unitless factor), and the initial slope $(\alpha)$ of the productivity versus radiance curve for phytoplankton growth $\left(\mathrm{day}^{-1} /\left(\mathrm{W} \mathrm{m}^{-2}\right)\right) . Q_{O}^{P}$ gives the up- 

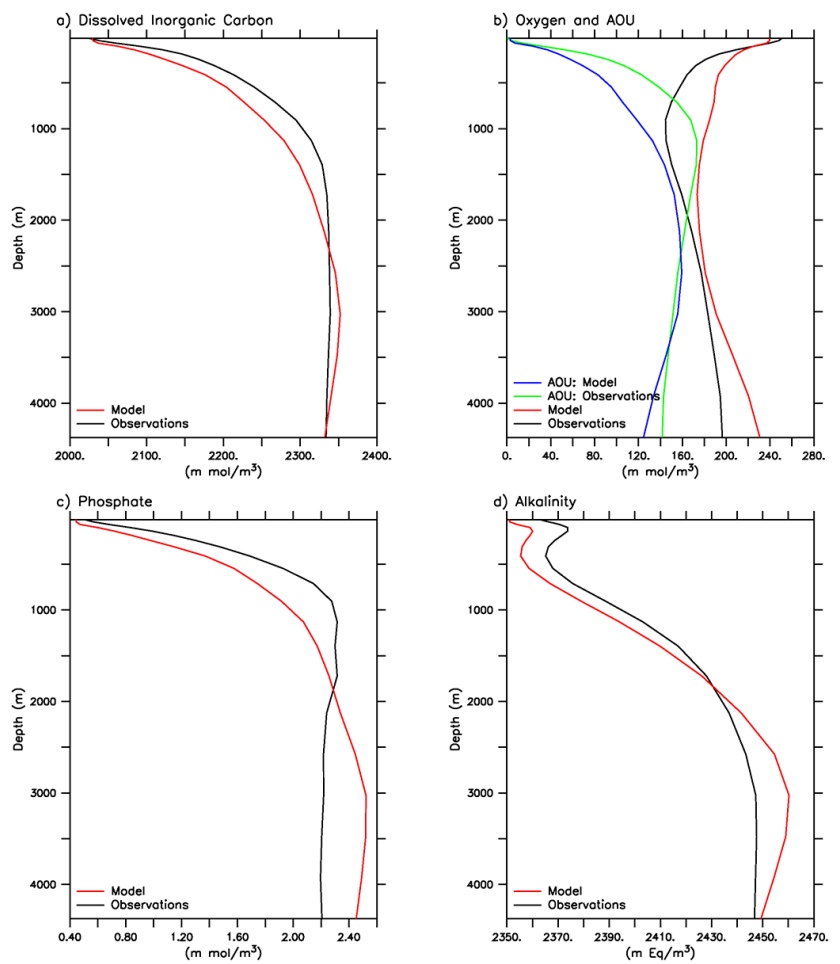

Figure A2. Comparison of the global averaged profiles of the REF simulation in the year 1850 with the observations for (a) preindustrial dissolved inorganic carbon; (b) dissolved oxygen and apparent oxygen utilisation; (c) phosphate and (d) alkalinity in units of mmol m${ }^{-3}$. The observed fields come from (Key et al., 2004) and (Boyer et al., 2009).

take of phosphate for POP production in $\mathrm{mmol} \mathrm{P} \mathrm{m}^{-3}$ day $^{-1}$ in the photic zone. $Q_{O}^{P}$ is a function of a growth limitation function, a maximum temperature-dependent phytoplankton growth rate and a constant $\left(S_{\mathrm{npp}}^{\mathrm{o}}\right)$. The growth limitation function uses the minimum value of light- and phosphatelimited growth. The phosphate-limited growth term is based on the phosphate concentration of the surface layer $P$ and the half saturation uptake $\left(P_{k}\right)$ value for phosphate utilisation, which was set to $0.1 \mathrm{mmolPm}^{-3}$. The constant $S_{\mathrm{npp}}^{\mathrm{o}}$ converts the phytoplankton growth rate into organic matter available for export and its value $\left(0.005 \mathrm{mmol} \mathrm{P} \mathrm{m}^{-3}\right)$ was manually tuned to satisfactorily reproduce the observed phosphate and oxygen concentrations. Finally, $E_{\mathrm{POP}}$ gives the production of particulate organic phosphorous in the photic zone $\left(\mathrm{mmolP} \mathrm{m}{ }^{-2}\right.$ day $\left.^{-1}\right)$, where $\Delta z$ is the thickness of the surface layer in metres $(50 \mathrm{~m})$.

The POP uptake in the photic zone was linked to inorganic carbon, oxygen and alkalinity uptake in the photic zone by the following equations:

$Q_{O}^{C}=106 Q_{O}^{P}$

$Q_{O}^{O}=-136 Q_{O}^{P}$

$Q_{O}^{A}=-16 Q_{O}^{P}$
Particulate inorganic carbon production in the model was linked to particulate organic carbon (POC) production by using a fixed rain ratio $\left(r^{\circ}\right)$ of $9 \%$ (Yamanaka and Tajika, 1996) as follows:

$$
\begin{aligned}
E_{\mathrm{POC}} & =106 Q_{O}^{P} \Delta z=Q_{O}^{C} \Delta z \\
E_{\mathrm{PIC}} & =r^{\mathrm{o}} \times 106 Q_{O}^{P} \Delta z=r^{\mathrm{o}} \times Q_{O}^{C} \Delta z
\end{aligned}
$$

to give the following uptake of inorganic carbon and alkalinity in the photic zone:

$$
\begin{aligned}
& Q_{I}^{C}=r^{\mathrm{o}} \times 106 Q_{O}^{P} \\
& Q_{I}^{A}=r^{v} \times 2 \times 106 Q_{O}^{P}, \quad r^{\mathrm{o}}=0.09
\end{aligned}
$$

The POP, POC and PIC produced in the photic zone were vertically exported from the photic zone and instantaneously remineralised in the ocean interior according to the following equations.

$$
\begin{aligned}
Q_{O}^{P} & =E_{\mathrm{POC}} / 106 \frac{\partial}{\partial z}[R(z)] \\
Q_{O}^{C} & =E_{\mathrm{POC}} \frac{\partial}{\partial z}[R(z)] \\
Q_{I}^{C} & =E_{\mathrm{PIC}} \frac{\partial}{\partial z}[D(z)],
\end{aligned}
$$

where

$$
\begin{aligned}
R(z) & =\frac{z}{100 m}^{\text {REMINPOC }_{\text {P }}} \\
D(z) & =\exp \left(z / \text { REMIN }_{\mathrm{PIC}}\right)
\end{aligned}
$$

are normalised vertical depth profiles of POC and PIC, respectively, $z$ is depth in metres, REMIN $N_{P O C}=-0.9$ sets the remineralisation length scale of POC and REMIN PIC $=$ $3500 \mathrm{~m}$ sets the depth scale for PIC dissolution (Yamanaka and Tajika, 1996).

There is no remineralisation above $100 \mathrm{~m}$ and all the POM and PIC reaching the ocean bottom are remineralised in the bottom layer of the model. The relationship between POC remineralisation and phosphate, oxygen and alkalinity is given by Eqs. (A8-A10).

Further, the remineralisation of POC also occurs in anoxic regions through denitrification. This occurs by remineralising the POM back into its inorganic constituents without consuming any oxygen. The remineralisation of POM in the denitrification regions increases alkalinity in the same manner as the aerobic respiration (Eq. A10), which is not correct (Paulmier et al., 2009) but the error is actually small and it was done to ensure alkalinity was conserved in the ocean.

The oceanic biogeochemical model was initially spun up using fields from the final stages of the physical ocean component spin-up conducted prior to initiation of the control Earth system model integration. The biogeochemical model is then integrated as described above over the duration of the climate model integrations. For comparison, we show 
the zonally averaged sections of dissolved inorganic carbon and alkalinity from the preindustrial period (year 1850) compared to the observed fields (Fig. A1). The model generally captures the observed variability with the spatial correlation of three-dimensional alkalinity and dissolved inorganic carbon with observations (Key et al., 2004) being 0.92 and 0.91 , respectively. Also shown are comparisons of the global averaged profiles of alkalinity, preindustrial dissolved inorganic carbon, phosphate, dissolved oxygen and apparent oxygen utilisation with the observations (Key et al., 2004; Boyer et al., 2009) (Fig. A2). In the intermediate water (500$1500 \mathrm{~m}$ ), the model underestimates phosphate, dissolved inorganic carbon and apparent oxygen utilisation concentrations and this implies the model is underestimating the remineralisation of POM in the intermediate water. 
Acknowledgements. Funding for this work was provided by the Australian Climate Change Science Program, the Pacific-Australia Climate Change Science and Adaptation Planning Program, and the CSIRO Wealth from Oceans Flagship.

Edited by: M. Grégoire

\section{References}

Archer, D. E., Eshel, G., Winguth, A., Broecker, W., Pierrehumbert, R., Tobis, M., and Jacob, R.: Atmospheric $p \mathrm{CO}(2)$ sensitivity to the biological pump in the ocean, Global Biogeochem. Cy., 14, 1219-1230, 2000.

Armstrong, R. A., Lee, C., Hedges, J. I., Honjo, S., and Wakeham, S. G.: A new, mechanistic model for organic carbon fluxes in the ocean based on the quantitative association of POC with ballast minerals, Deep Sea Res. Pt. II, 49, 219-236, 2002.

Arnold, H. E., Kerrison, P., and Steinke, M.: Interacting effects of ocean acidification and warming on growth and DMS-production in the haptophyte coccolithophore Emiliania huxleyi, Glob. Change Biol., 19, 1007-1016, 2013.

Aumont, O. and Bopp, L.: Globalizing results from ocean in situ iron fertilization studies, Global Biogeochem. Cycles, 20, GB2017, doi:10.1029/2005GB002591, 2006.

Bellerby, R. G. J., Schulz, K. G., Riebesell, U., Neill, C., Nondal, G., Heegaard, E., Johannessen, T., and Brown, K. R.: Marine ecosystem community carbon and nutrient uptake stoichiometry under varying ocean acidification during the PeECE III experiment, Biogeosciences, 5, 1517-1527, doi:10.5194/bg-5-15172008, 2008.

Bopp, L., Quere, C. L., Heimann, M., Manning, A. C., and Monfray, P.: Climate-induced oceanic oxygen fluxes: Implications for the contemporary carbon budget, Global Biogeochem. Cy., 16, 1022, doi:10.1029/2001GB001445, 2002.

Bopp, L., Resplandy, L., Orr, J. C., Doney, S. C., Dunne, J. P., Gehlen, M., Halloran, P., Heinze, C., Ilyina, T., Séférian, R., Tjiputra, J., and Vichi, M.: Multiple stressors of ocean ecosystems in the 21st century: projections with CMIP5 models, Biogeosciences, 10, 6225-6245, doi:10.5194/bg-10-6225-2013, 2013

Boyer, T. P., Antonov, J. I., Baranova, O. K., Garcia, H. E., Johnson, D. R., Locarnini, R. A., Mishonov, A. V., O'Brien, T., Seidov, D., and Smolyar, I. V.: World Ocean Database 2009, Vol. 66, NOAA Atlas NESDIS, U.S. Gov. Printing Office, Wash., D.C., 2009.

Breitbarth, E., Bellerby, R. J., Neill, C. C., Ardelan, M. V., Meyerhöfer, M., Zöllner, E., Croot, P. L., and Riebesell, U.: Ocean acidification affects iron speciation during a coastal seawater mesocosm experiment, Biogeosciences, 7, 1065-1073, doi:10.5194/bg-7-1065-2010, 2010.

Brewer, P. G. and Peltzer, E. T.: Oceans: Limits to marine life, Science, 324, 347-348, 2009.

Brohan, P., Kennedy, J. J., Harris, I., Tett, S. F. B., and Jones, P. D.: Uncertainty estimates in regional and global observed temperature changes: A new data set from 1850, J. Geophys. Res.Atmos., 111, D12106, doi:10.1029/2005JD006548, 2006.

Caldeira, K.: Ocean model predictions of chemistry changes from carbon dioxide emissions to the atmosphere and ocean, J. Geophys. Res., 110, C09S04, 2005.
Cameron-Smith, P., Elliott, S., Maltrud, M., Erickson, D., and Wingenter, O.: Changes in dimethyl sulfide oceanic distribution due to climate change, Geophys. Res. Lett., 38, L07704, doi:10.1029/2011GL047069, 2011.

Canadell, J. G., Le Quere, C., Raupach, M. R., Field, C. B., Buitenhuis, E. T., Ciais, P., Conway, T. J., Gillett, N. P., Houghton, R. A., and Marland, G.: Contributions to accelerating atmospheric $\mathrm{CO} 2$ growth from economic activity, carbon intensity, and efficiency of natural sinks, P. Natl. Acad. Sci. USA, 104, 18 866-18 870, 2007.

Cocco, V., Joos, F., Steinacher, M., Frölicher, T. L., Bopp, L., Dunne, J., Gehlen, M., Heinze, C., Orr, J., Oschlies, A., Schneider, B., Segschneider, J., and Tjiputra, J.: Oxygen and indicators of stress for marine life in multi-model global warming projections, Biogeosciences, 10, 1849-1868, doi:10.5194/bg-10-18492013, 2013.

Dentener, F.: Global maps of atmospheric nitrogen deposition, 1860, 1993, and 2050, Data set, available at: http://daac.ornl.gov/ from Oak Ridge National Laboratory Distributed Active Archive Center, Oak Ridge, Tennessee, USA, 2006.

Doney, S. C., Fabry, V. J., Feely, R. A., and Kleypas, J. A.: Ocean Acidification: The Other $\mathrm{CO}_{2}$ Problem, Annu. Rev. Mar. Sci., 1, 169-192, 2009.

Duteil, O., Koeve, W., Oschlies, A., Aumont, O., Bianchi, D., Bopp, L., Galbraith, E., Matear, R., Moore, J. K., Sarmiento, J. L., and Segschneider, J.: Preformed and regenerated phosphate in ocean general circulation models: can right total concentrations be wrong?, Biogeosciences, 9, 1797-1807, doi:10.5194/bg-9-1797-2012, 2012.

Duteil, O., Koeve, W., Oschlies, A., Bianchi, D., Galbraith, E., Kriest, I., and Matear, R.: A novel estimate of ocean oxygen utilisation points to a reduced rate of respiration in the ocean interior, Biogeosciences, 10, 7723-7738, doi:10.5194/bg-10-7723-2013, 2013.

Fabry, V., Seibel, B., Feely, R., and Orr, J.: Impacts of ocean acidification on marine fauna and ecosystem processes, ICES J. Mar. Sci. 65, 414-432, 2008.

Gabric, A., Murray, N., Stone, L., and Kohl, M.: Modelling the proeduction of dimethylsulfide during a phytoplankton bloom, J. Geophys. Res., 98, 22805-22816, 1993.

Gabric, A., Qu, B., Matrai, P., and Hirst, A.: The simulated response of dimethylsulfide production in the Arctic Ocean to global warming, Tellus B, 57, 391-403, 2011.

Gehlen, M., Gruber, N., Gangstø, R., Bopp, L., and Oschlies, A.: Biogeochemical consequences of ocean acidification and feedbacks to the earth system, in: Ocean Acidification, vol. 1, edited by: Gattuso, J.-P. and Hansson, L., 230-248, Oxford University Press, 2011.

Glessmer, M. S., Eden, C., and Oschlies, A.: Contribution of oxygen minimum zone waters to the coastal upwelling off Mauritania, Prog. Oceanogr., 83, 143-150, 2009.

Gruber, N. and Galloway, J.: An earth-system perspective of the global nitrogen cycle, Nature, 451, 293-296, 2008.

Guinotte, J. M., Buddemeier, R. W., and Kleypas, J. A.: Future coral reef habitat marginality: temporal and spatial effects of climate change in the Pacific basin, Coral Reefs, 22, 551-558, doi:10.1007/s00338-003-0331-4, 2003.

Hedin, L. O.: Global organization of terrestrial plant-nutrient interactions, Proc. Natl. Acad. Sci. USA, 101, 10849-10850, 2004. 
Heinze, C.: Simulating oceanic $\mathrm{CaCO}_{3}$ export production in the greenhouse, Geophys. Res. Lett., 31, L16308, doi:10.1029/2004GL020613, 2004.

Hoffmann, L. J., Breitbarth, E., Boyd, P. W., and Hunter, K. A.: Influence of ocean warming and acidification on trace metal biogeochemistry, Mar. Ecol.-Prog. Ser., 470, 191-205, doi:10.3354/meps10082, 2012.

Hopkins, F., Nightingale, P., and Liss, P.: Effects of ocean acidification on the marine source of atmospherically active trace gases, in: Ocean Acidification, edited by: Gattuso, J.-P. and Hansson, L., p. 210, Oxford University Press, 2011.

Hutchins, D. A.: Oceanography: forecasting the rain ratio, Nature, 476, 41-42, 2011.

Hutchins, D. A., Mulholland, M. R., and Fu, F.: Nutrient cycles and marine microbes in a $\mathrm{CO}_{2}$-enriched ocean, Oceanography, 22, 128-145, 2009.

Key, R. M., Kozyr, A., Sabine, C. L., Lee, K., Wanninkhof, R., Bullister, J. L., Feely, R. A., Millero, F. J., Mordy, C., and Peng, T. H.: A global ocean carbon climatology: Results from Global Data Analysis Project (GLODAP), Global Biogeochem. Cy., 18, GB4031, doi:10.1029/2004GB002247, 2004.

Khatiwala, S., Primeau, F., and Hall, T.: Reconstruction of the history of anthropogenic $\mathrm{CO}_{2}$ concentrations in the ocean, Nature, 462, 346-349, 2009.

Kloster, S., Six, K. D., Feichter, J., Maier-Reimer, E., Roeckner, E., Wetzel, P., Stier, P., and Esch, M.: Response of dimethylsulfide (DMS) in the ocean and atmosphere to global warming, J. Geophys. Res., 112, G03005, doi:10.1029/2006JG000224, 2007.

Lawrence, P. J., Feddema, J. J., Bonan, G. B., Meehl, G. A., O'Neill, B. C., Oleson, K. W., Levis, S., Lawrence, D. M., Kluzek, E., Lindsay, K., and Thornton, P. E.: Simulating the biogeochemical and biogeophysical impacts of transient land cover change and wood harvest in the Community Climate System Model (CCSM4) from 1850 to 2100, J. Climate, 25, 3071-3095, 2013.

Mao, J., Phipps, S. J., Pitman, A. J., Wang, Y. P., Abramowitz, G., and Pak, B.: The CSIRO Mk3L climate system model v1.0 coupled to the CABLE land surface scheme v1.4b: evaluation of the control climatology, Geosci. Model Dev., 4, 1115-1131, doi:10.5194/gmd-4-1115-2011, 2011.

Matear, R. J. and Elliott, B.: Enhancement of oceanic uptake of anthropogenic $\mathrm{CO}_{2}$ by macro-nutrient fertilization, J. Geophys. Res., 109, C4001, doi:10.1029/2000JC000321, 2004.

Matear, R. J. and Hirst, A. C.: Climate Change Feedback on the Future Oceanic $\mathrm{CO}_{2}$ uptake, Tellus, 51B, 722-733, 1999.

Matear, R. J. and Hirst, A. C.: Long term changes in dissolved oxygen concentrations in the ocean caused by protracted global warming, Global Biogeochem. Cy., 17, 1125, doi:10.1029/2002GB001997, 2003.

Matear, R. J. and Wong, C. S.: Potential to increase the oceanic $\mathrm{CO}_{2}$ uptake by enhancing marine productivity in high nutrient low chlorophyll regions, 249-253, 1999.

Matear, R. J., Hirst, A. C., and McNeil, B. I.: Changes in dissolved oxygen in the Southern Ocean with climate change, Geochemistry Geophysics Geosystems (http://gcubed.magnet. fsu.edu/main.html), 1, 2000.

Matear, R. J., Wang, Y.-P., and Lenton, A.: Land and ocean nutrient and carbon cycle interactions, Curr. Op. Environ. Sustain., 2, 258-263, 2010.
Matsumoto, K., Sarmiento, J. L., Key, R. M., Aumont, O., Bullister, J. L., Caldeira, K., Campin, J. M., Doney, S. C., Drange, H., Dutay, J. C., Follows, M. J., Gao, Y., Gnanadesikan, A., Gruber, N., Ishida, A., Joos, F., Lindsay, K., Maier-Reimer, E., Marshall, J. C., Matear, R. J., Monfray, P., Mouchet, A., Najjar, R., Plattner, G. K., Schlitzer, R., Slater, R., Swathi, P. S., Totterdell, I. J., Weirig, M. F., Yamanaka, Y., Yool, A., and Orr, J. C.: Evaluation of ocean carbon cycle models with data-based metrics, Geophys. Res. Lett., 31, L07303, doi:10.1029/2003GL018970, 2004.

Najjar, R. G., Jin, X., Louanchi, F., Aumont, O., Caldeira, K., Doney, S. C., Dutay, J. C., Follows, M. J., Gruber, N., Joos, F., Lindsay, K., Maier-Reimer, E., Matear, R. J., Matsumoto, K., Monfray, P., Mouchet, A., Orr, J. C., Plattner, G. K., Sarmiento, J. L., Schlitzer, R., Slater, R. D., Weirig, M. F., Yamanaka, Y., and Yool, A.: Impact of circulation on export production, dissolved organic matter, and dissolved oxygen in the ocean: Results from Phase II of the Ocean Carbon-cycle Model Intercomparison Project (OCMIP-2), Global Biogeochem. Cy., 21, GB3007, doi:10.1029/2006GB002857, 2007.

Orr, J. C., Fabry, V. J., Aumont, O., Bopp, L., Doney, S. C., Feely, R. A., Gnanadesikan, A., Gruber, N., Ishida, A., Joos, F., Key, R. M., Lindsay, K., Maier-Reimer, E., Matear, R. J., Monfray, P., Mouchet, A., Najjar, R. G., Plattner, G. K., Rodgers, K. B., Sabine, C. L., Sarmiento, J. L., Schlitzer, R., Slater, R. D., Totterdell, I. J., Weirig, M. F., Yamanaka, Y., and Yool, A.: Anthropogenic ocean acidification over the twentyfirst century and its impact on calcifying organisms, Nature, 437, 681-686, 2005.

Oschlies, A., Schulz, K. G., Riebesell, U., and Schmittner, A.: Simulated 21st century's increase in oceanic suboxia by $\mathrm{CO}_{2}$ enhanced biotic carbon export, Global Biogeochem. Cy., 22, GB4008, doi:10.1029/2007GB003147, 2008.

Paulmier, A., Kriest, I., and Oschlies, A.: Stoichiometries of remineralisation and denitrification in global biogeochemical ocean models, Biogeosciences, 6, 923-935, doi:10.5194/bg-6923-2009, 2009.

Phipps, S. J., Rotstayn, L. D., Gordon, H. B., Roberts, J. L., Hirst, A. C., and Budd, W. F.: The CSIRO Mk3L climate system model version 1.0 - Part 1: Description and evaluation, Geosci. Model Dev., 4, 483-509, doi:10.5194/gmd-4-483-2011, 2011.

Pinsonneault, A. J., Matthews, H. D., Galbraith, E. D., and Schmittner, A.: Calcium carbonate production response to future ocean warming and acidification, Biogeosciences, 9, 2351-2364, doi:10.5194/bg-9-2351-2012, 2012.

Pitman, A. J., Avila, F. B., Abramowitz, G., Wang, Y. P., Phipps, S. J., and de Noblet-Ducoudré, N.: Importance of background climate in determining impact of land-cover change on regional climate, Nat. Clim. Change, 1, 472-475, 2011.

Portner, H. O. and Farrell, A. P.: ECOLOGY: physiology and climate change, Science, 322, 690-692, doi:10.1126/science.1163156, 2008.

Raven, J. A.: Ocean Acidification Due to Increasing Atmospheric Carbon Dioxide, R Society (Great Britain), 60 pp., 2005.

Redfield, A. C.: On the proportions of organic derivatives in sea water and their relation to the composition of plankton, in James Johnstone Memorial Volume, ed. R. J. Daniel, 172-192, 1934.

Ridgwell, A., Schmidt, D. N., Turley, C., Brownlee, C., Maldonado, M. T., Tortell, P., and Young, J. R.: From laboratory ma- 
nipulations to Earth system models: scaling calcification impacts of ocean acidification, Biogeosciences, 6, 2611-2623, doi:10.5194/bg-6-2611-2009, 2009.

Riebesell, U., Schulz, K. G., Bellerby, R. G. J., Botros, M., Fritsche, P., Meyerhofer, M., Neill, C., Nondal, G., Oschlies, A., Wohlers, J., and Zollner, E.: Enhanced biological carbon consumption in a high $\mathrm{CO}_{2}$ ocean, Nature, 450, 545-549, 2007.

Rivkin, R. B.: Biogenic Carbon Cycling in the Upper Ocean: Effects of Microbial Respiration, Science, 291, 2398-2400, 2001.

Rost, B., Zondervan, I., and Wolf-Gladrow, D.: Sensitivity of phytoplankton to future changes in ocean carbonate chemistry: current knowledge, contradictions and research directions, Mar. Ecol.Prog. Ser., 373237., 227, 227-237, 2008.

Schmittner, A., Oschlies, A., Matthews, H. D., and Galbraith, E. D.: Future changes in climate, ocean circulation, ecosystems, and biogeochemical cycling simulated for a business-as-usual $\mathrm{CO}_{2}$ emission scenario until year $4000 \mathrm{AD}$, Global Biogeochem. Cy., 22, GB1013, doi:10.1029/2007GB002953, 2008.

Shi, D., Xu, Y., Hopkinson, B., and Morel, F.: Effect of ocean acidification on iron availability to marine phytoplankton, Science, 327, 676, doi:10.1126/science.1183517,, 2010.

Six, K. D., Kloster, S., Ilyina, T., Archer, S. D., Zhang, K., and Maier-Reimer, E.: Global warming amplified by reduced sulphur fluxes as a result of ocean acidification, Nat. Clim. Change, 3, $1-4,2013$

Tagliabue, A., Bopp, L., and Gehlen, M.: The response of marine carbon and nutrient cycles to ocean acidification: large uncertainties related to phytoplankton physiological assumptions, Global Biogeochem. Cy., 25, GB3017, doi:10.1029/2010GB003929, 2011.

Taylor, K. E.: Summarizing multiple aspects of model performance in a single diagram, J. Geophys. Res.-Atmos., 106, 7183-7192, 2001.

Trenberth, K. E., Jones, P. D., Ambenje, P., Bojariu, R., Easterling, D., Tank, A. K., Parker, D., Rahimzadeh, F., Renwick, J. A., Rusticucci, M., Soden, B., and Zhai, P.: Observations: Surface and Atmospheric Climate Change, 2007.
Trull, T. W., Bray, S. G., Manganini, S. J., Honjo, S., and Francois, R.: Moored sediment trap measurements of carbon export in the Subantarctic and Polar Frontal Zones of the Southern Ocean, south of Australia, J. Geophys. Res.-Atmos., 106, 31489-31509, 2001.

Wang, Y. P., Law, R. M., and Pak, B.: A global model of carbon, nitrogen and phosphorus cycles for the terrestrial biosphere, Biogeosciences, 7, 2261-2282, doi:10.5194/bg-7-2261-2010, 2010.

Wanninkhof, R.: Relationship between wind speed and gas exchange over the ocean, J. Geophys. Res., 97, 7373-7382, 1992.

Weinbauer, M. G., Mari, X., and Gattuso, J.-P.: Effects of ocean acidification on the diversity and activity of heterotrophic marine microorganisms, in: Ocean Acidification, edited by: Gattuso, J.P. and Hansson, L., Oxford University Press, 2011.

Weiss, R. F.: The solubility of nitrogen, oxygen and argon in water and seawater, Deep Sea Res., 17, 721-735, 1970.

Yamanaka, Y. and Tajika, E.: The role of the vertical fluxes of particulate organic matter and calcite in the oceanic carbon cycle: studies using a ocean biogeochemical general circulation model, Global Biogeochem. Cy., 10, 361-382, 1996.

Zaehle, S., Friedlingstein, P., and Friend, A. D.: Terrestrial nitrogen feedbacks may accelerate future climate change, Geophys. Res. Lett., 37, L01401, doi:10.1029/2009GL041345, 2010.

Zhang, Q., Wang, Y. P., Matear, R. J., Pitman, A. J., and Dai, Y. J.: Nitrogen and phosphorous limitations significantly reduce future allowable $\mathrm{CO}_{2}$ emissions, Geophys. Res. Lett., doi:10.1002/2013GL058352, 2014.

Zondervan, I., Rost, B., and Riebesell, U.: Effect of $\mathrm{CO}_{2}$ concentration on the PIC/POC ratio in the coccolithophore Emiliania huxleyi grown under light-limiting conditions and different daylengths, J. Exp. Mar. Biol. Ecol., 272, 55-70, 2002. 